\title{
Dromedary (Camelus dromedarius) and Bactrian camel (Camelus bactrianus) crossbreeding husbandry practices in Turkey and Kazakhstan: An in-depth review
}

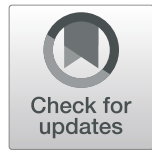

Maurizio Diolio

\begin{abstract}
Hybridization between dromedaries and Bactrian camels has been carried out since ancient times in various areas of the Middle East and Central Asia. The primary force behind such practice was to obtain a better pack camel for trade caravans and military interventions. Today, camel hybridization is carried out systematically in only two areas: Turkey and Kazakhstan. In Turkey, camel cross-breeding is mainly done to obtain large animals for the annual camel wrestling competitions, while in Kazakhstan, cross-breeding is done to obtain camels that are more productive and better able to resist the harsh climate of Central Asia.
\end{abstract}

Keywords: Arabian camel, One-humped camel, Dromedary, Camelus dromedarius, Camel, Two-humped camel, Bactrian camel, Camelus bactrianus, Hybridization

\section{Introduction}

The dromedary, also known as one-humped camel or Arabian camel (Camelus dromedarius), and the Bactrian camel or two-humped camel or simply camel (Camelus bactrianus) are two distinctive and recognizable livestock species commonly found in Africa, the Middle East, and Asia. The two species occupy disparate geographic areas, with the dromedary found in the northern part of Africa, the Middle East, part of Asia, and the Indian subcontinent, while the Bactrian camel is found only in inner, central and east Asia: China, Mongolia, Kazakhstan, Kirghizstan, Turkmenistan, and Afghanistan, northern areas of Iran, India, Pakistan and up to eastern Turkey (Fig. 1). Presentday Bactrian camel distribution is much smaller than the area occupied by the dromedary, which is essentially limited to areas with a mean annual temperature not much over $21{ }^{\circ} \mathrm{C}$ (Mason 1979). This was not always the case. since historically, certainly from first millennia BCE to the XVIII century CE, the distribution of the Bactrian camel was much wider, extending to include Russia, much of the Middle East, Turkey, the Balkans, and Eastern Europe, as

Correspondence: camel4ever@fastemail.us

Khartoum, Sudan indicated by archaeological remains (Mukhareva 2007; Potts 2005; Peters and Driesch 1997, Pigière and Henrotay 2012) and images of Bactrian camels on common objects such as Roman coins (Fig. 2). The dromedary and Bactrian camel, although taxonomically distinct species, are capable of interbreeding with each other. This produces a fertile F1 (first filial generation) hybrid that, thanks to the hybrid vigour or heterosis arising from the interaction between parental genomes, has a better growth rate and productivity than that of their pure-bred parents (Dzhumagulov 1980; Baimukanov 2002). More importantly, F1 hybrids are capable of withstanding colder, wetter climates and rough terrains with greater ease. These peculiarities were powerful incentives toward the development by various ethnic groups of structured cross-breeding husbandry practices between dromedary and Bactrian camels. It is postulated that dromedary-Bactrian camel cross-breeding was initiated around the second century $\mathrm{BCE}$, or even much earlier, particularly in areas where the distribution of the two species overlapped or wherever female dromedaries were common and Bactrian camels could be easily obtained: in various areas of the Middle East, Turkey, from Iran, Iraq to southern Arabia, and from Turkmenistan to northern Afghanistan (Bulliet 1975, 2009; Potts 2004, 2005; Uerpmannh 1999). 


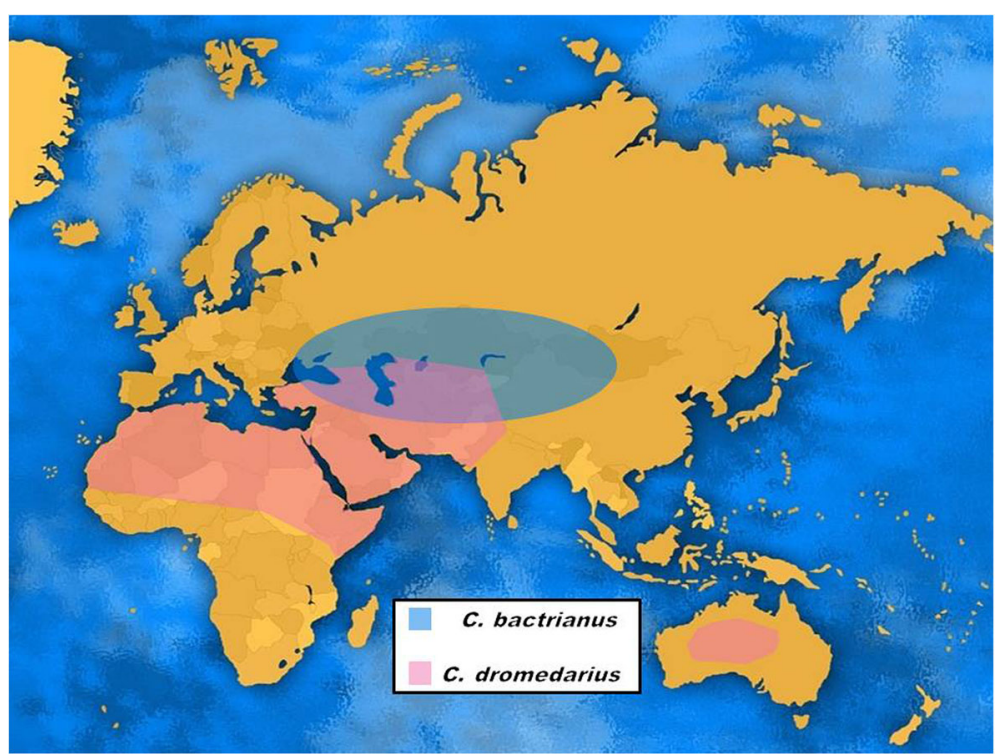

Fig. 1 Map of approximate distribution and overlapping of Camelus dromedarius and Camelus bactrianus. www.maxpixel.net

\section{Historical dromedary-Bactrian camel cross- breeding husbandry practices}

The main driver of dromedary and Bactrian crossbreeding practices was the need to obtain strong pack camels capable of withstanding rough terrains and the colder, wet climates of geographical areas with large trade volumes and subjected to military conquests and campaigns. These geographical areas included modern day area of Turkey, Balkans, and northern and eastern Europe. The exceptional loading capacity of hybrid camels is

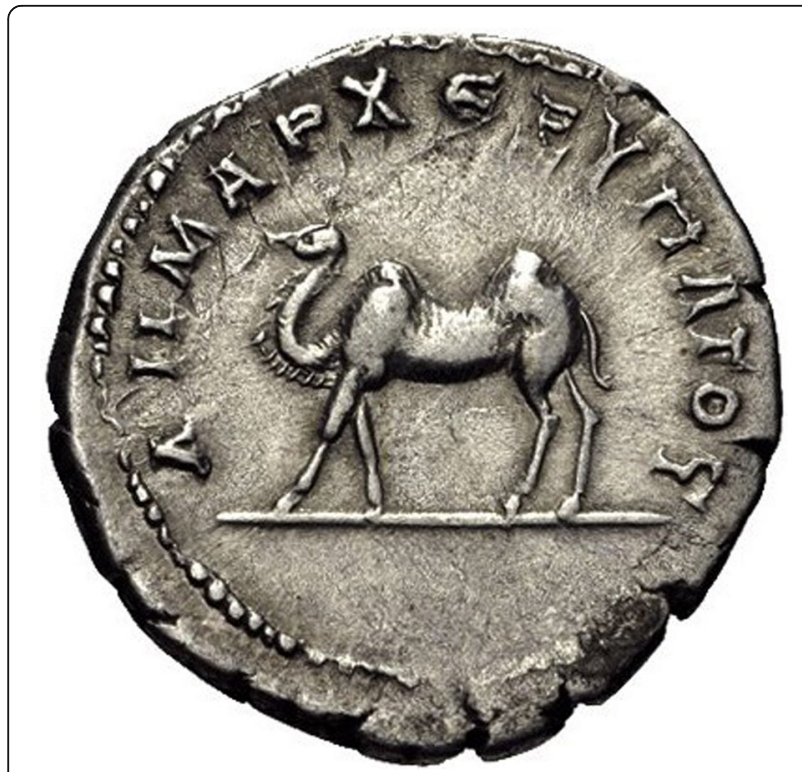

Fig. 2 Roman coin from the Roman province of Arabia, Bostra Syria Decapolis AD 98-117. www.catawiki.com documented repeatedly (Bulliet 2009; Tapper 1985, 2011) and is probably the reason why skeletal remains of hybrid camels have been found in various archaeological sites where trade centres and military garrisons were located. Such sites can be found all over Turkey and northern, eastern, and central Europe (Pigière and Henrotay 2012; Vukovic and Bogdanovic 2013; Çakırlar and Berthon 2014; De Grossi Mazzorin 2006, 2010; Bartosiewicz 1996; Bartosiewicz and Dirjec 2001; Galik et al. 2015). The Ottoman army used hybrid camels extensively because of their exceptional loading capacity: $400-500 \mathrm{~kg}$ and ability to withstand cold and hilly terrains (Leese 1927; Burckhardt 1831; van Lennep 1870; Russell and Russell 1794). During the 1529 siege of Vienna by the Ottoman army, thousands of camels were used and scores ended up as spoils of war after the Ottoman defeat (Schimmer 1847). Such camels were probably the base for the image of the sixteenthcentury engraving by Niklas St $\mathrm{n}$ of a "Turk with camel and a dromedary" depicting a Bactrian camel that, by showing two very small humps close to each other, must be described as a hybrid between a dromedary and a Bactrian (Fig. 3). The description of an atrophic hump, anterior to the main hump, in adults and foetuses of the dromedaries bred at San Rossore, Italy, between the seventeenth and twentieth centuries (Lombardini 1879), is a further proof that camel hybridization was rather common in Europe (Dioli 2014, 2018). Camel cross-breeding was carried out by mating the male Bactrian camel with the female dromedary. Such an approach is confirmed by archaeological findings that have identified the dromedary as the maternal species used in the cross-breeding (Uerpmannh 


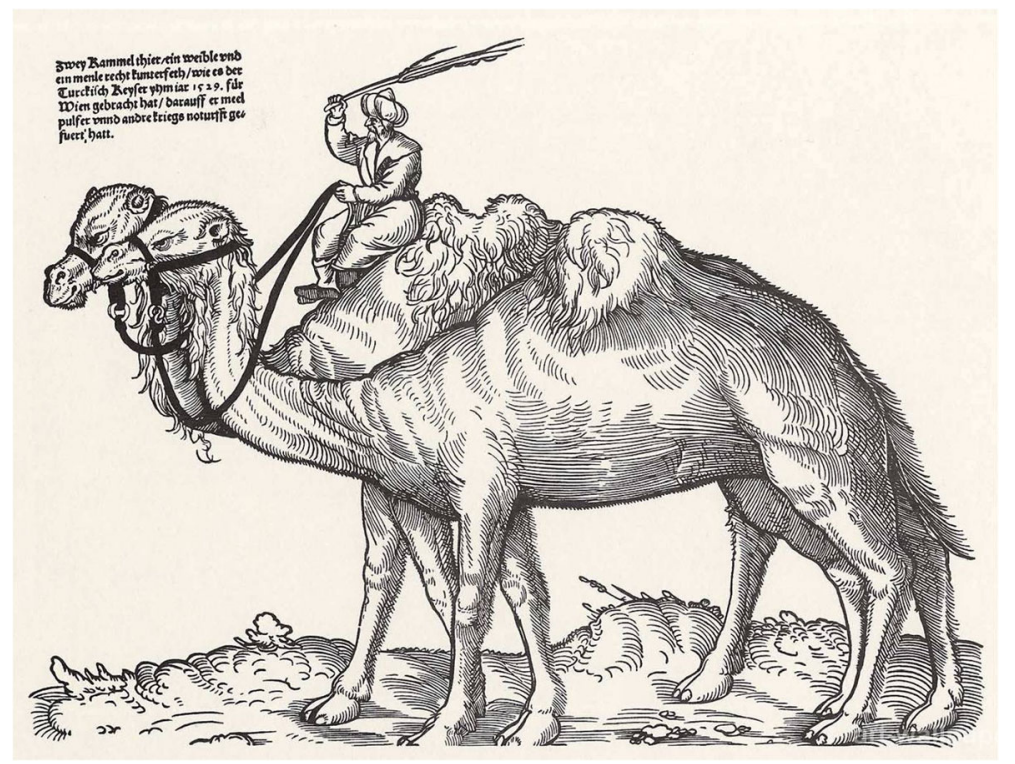

Fig. 3 Engraving of a "Turk with camel and a dromedary" from Niklas Stön dated 1530 showing the single indented hump typical of dromedary/ Bactrian hybrids (courtesy Herzogliches Museum Landenmuseum-Gotha, Germany)

1999). This cross-breeding practice was the most common method reported by several authors (Leonard 1894; Marsh 1856; Plassio 1912; Steel 1890) and mentioned by various regional travellers (Burckhardt 1831; Olearius 1669). A visual confirmation that this was indeed the cross-breeding practice used is even visible in an image of the famous sixteenth-century illuminated manuscript from Iran, Haft Awrang, in which an illustration shows a male Bactrian camel together with a female dromedary and between them their hybrid calf (Simpson 1997: 92). The first-generation hybrid F1 camel's loading capacity and ability to work in hilly terrains and cold environments was common knowledge. It was mentioned in the report documenting the nineteenth-century importation of dromedaries into the USA (United States Government Report 1857). In that report, Lieutenant Porter, who was responsible for the expedition, even suggested the importation of pure male Bactrian camels that could be bred with female dromedaries to produce F1 hybrids (United States Government Report 1857: 123). Further cross-breeding of F1 hybrid camels among themselves was rarely carried out since the resulting progeny was smaller, weaker, and "extremely vicious" or unable to cope with inclement weather (Burckhardt 1831; Fraser 1825; van Lennep 1870; Leonard 1894; Marsh 1856; Stewart 1881; Steel 1890). Another historical use of male Bactrian and female dromedary F1 hybrids was in the so-called camel wrestling events. Multiple mediaeval miniature paintings of Islamic art historians depicting camel wrestling from various geographic areas such as Afghanistan, western India, and Iran suggest that such events were relatively common (Adamova and Rogers 2004) (Fig. 4). In all historical illustrations of "camel wrestling", the animals represented are not pure-bred dromedaries or Bactrian camels but hybrid F1. While the presence of a single hump excludes them as pure-bred Bactrian camels, their hump is too large and elongated to be one of the pure-bred dromedaries. In addition, the abundant hairs all along the front side of the neck, the back and top of the head, and the forearms rule out such animals as dromedaries since these characteristics are absent in pure-bred dromedaries while constantly present in Bactrian camels. Wrestling camels in paintings are shown foaming at the mouth and without the "dulla" or soft palate, an organ present in the male dromedary but absent in the Bactrian camel and hybrids.

\section{Modern dromedary-Bactrian camel hybrid production}

Currently, camel hybridization is done in eastern Turkey (Yilmaz and Ertugrul 2014) and more extensively and in more structured ways in the former Soviet Republics of Kazakhstan and neighbouring Turkmenistan and Uzbekistan (Faye and Konuspayeva 2012; Baimukanov et al. 2019; Dzhumagulov 1980; Ruchkina and Vakhitova 2008). In Turkey, the main purpose of hybrid production is to obtain large camels for the annual "wrestling" events organized in the south-western part of the country during winter (Çakırlar and Berthon 2014; Yilmaz 2017; Yilmaz et al. 2015a, b, Yilmaz and Ertugrul 2014) (Fig. 5). In Kazakhstan and neighbouring countries, the focus of hybridization is to obtain camels better at milk, wool, and meat production while at the 


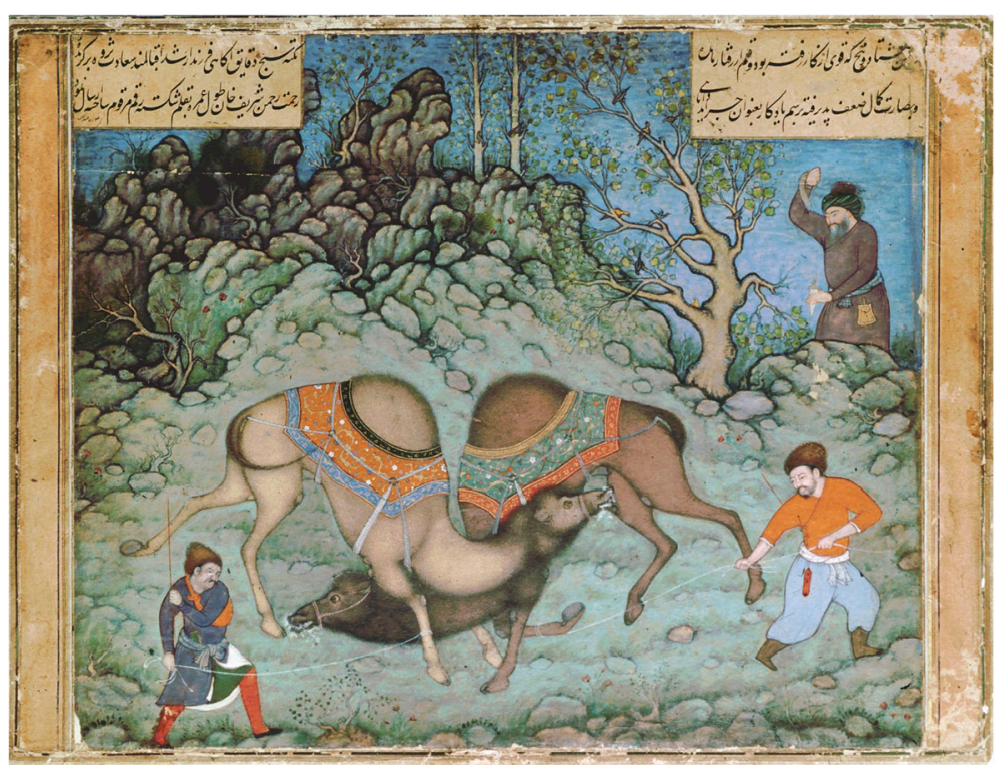

Fig. 4 Illustration from Abd al Samad: Two Fighting Camels, ca.1590. Wikimedia

Commons. https://commons.wikimedia.org/wiki/File:Abd_al_Samad._Two_Fighting_Camels_ca._1590._Private_Collection.jpg

same time more resilient to the harsh climate of Central Asia (Imamura et al. 2017).

\section{Hybrid production methods from Turkey}

In Turkey, hybrid production methods aim at producing a first-generation hybrid F1, occasionally a second generation F2 (second filial generation) and more rarely a third-generation hybrid F3 (third filial generation). Figure 6 is illustrates the various combinations of dromedary-Bactrian camel cross-breeding practices currently carried out in Turkey (Yilmaz and Ertuğrul 2015; Yilmaz et al. 2015a, b). The Turkish hybrid production method is the basic "two-breed" cross consisting of mating a male Bactrian camel with a female dromedary (Fig. 7). In Turkish, the common name of such F1 hybrid is tülü, more specifically besrek for male and maya for female (Yilmaz et al. 2015a, b). These hybrids are very similar in appearance to the dromedary, although they possess a larger and more elongated hump which starts from just behind the

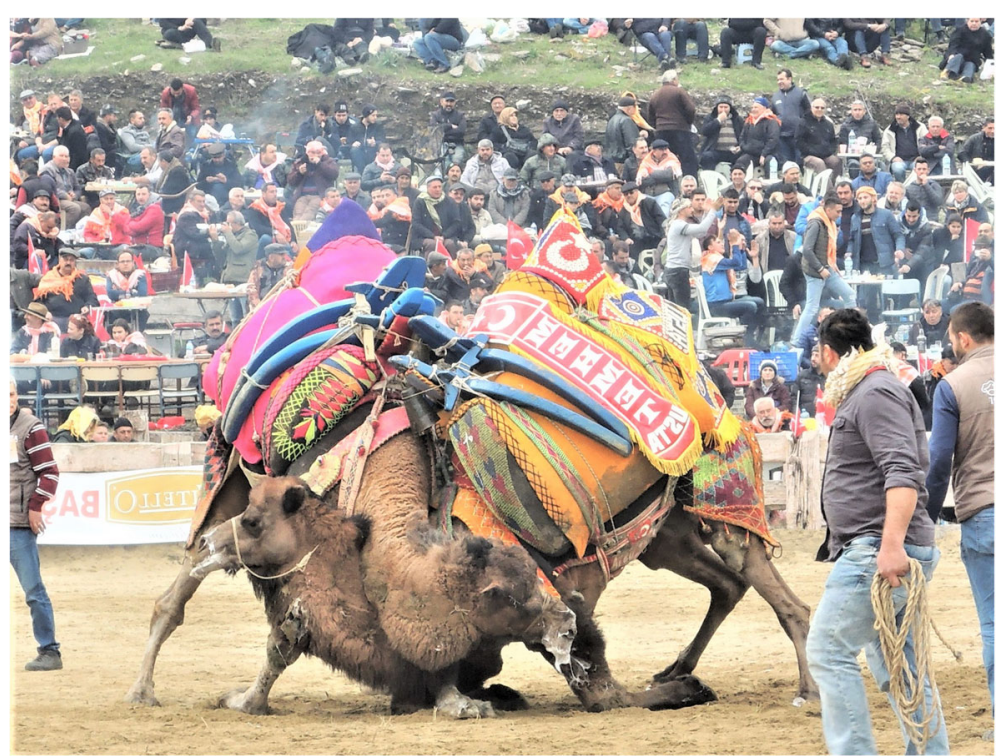

Fig. 5 Two male F1 hybrid camels wrestling at the 2018 Camel Wrestling Festival in Izmir, Turkey. Note the profuse foam at their mouth and the attendants ready to separate the camels once a victor has emerged. This will prevent injuries 


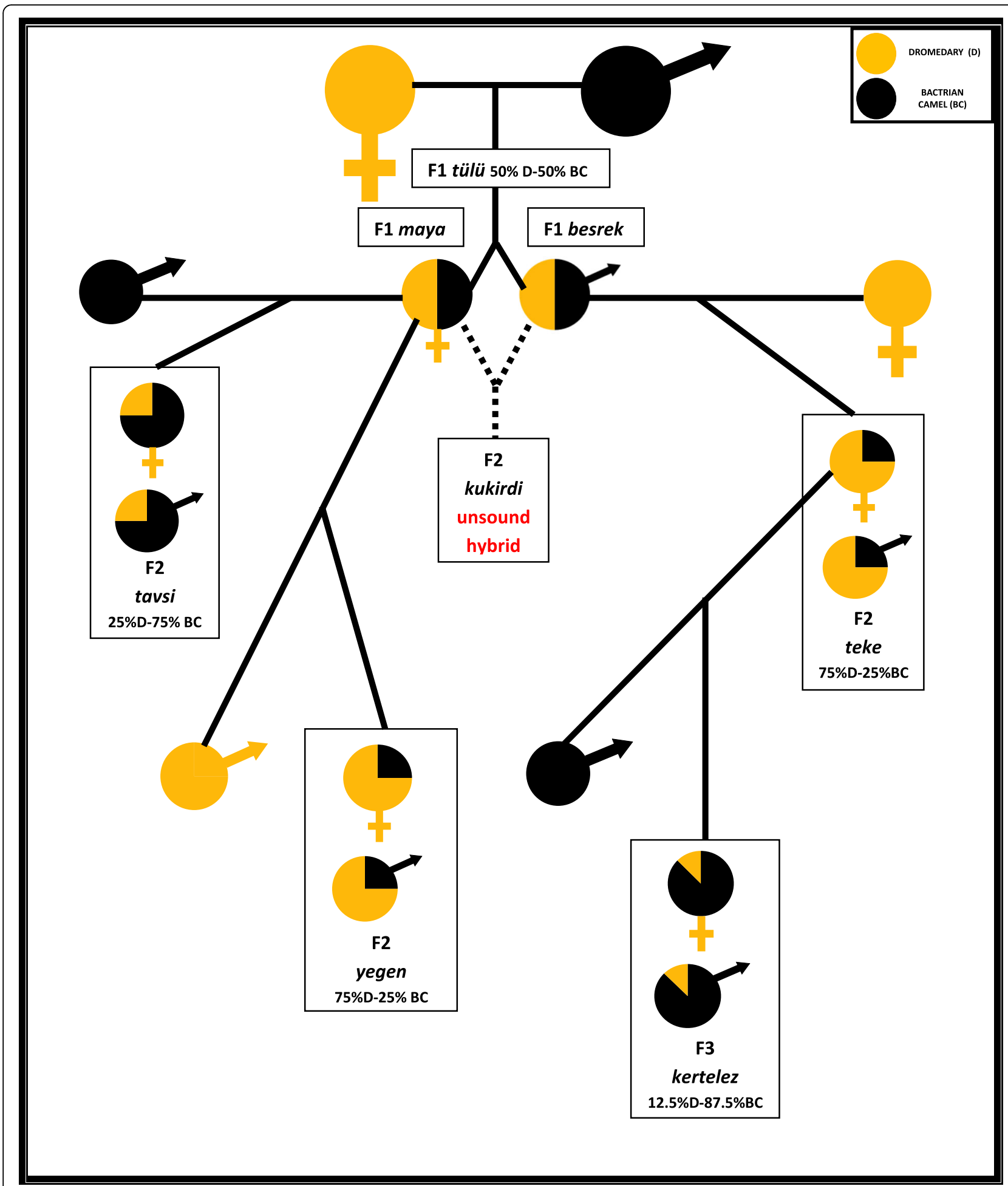

Fig. 6 Dromedary-Bactrian camel cross-breeding practices in Turkey 


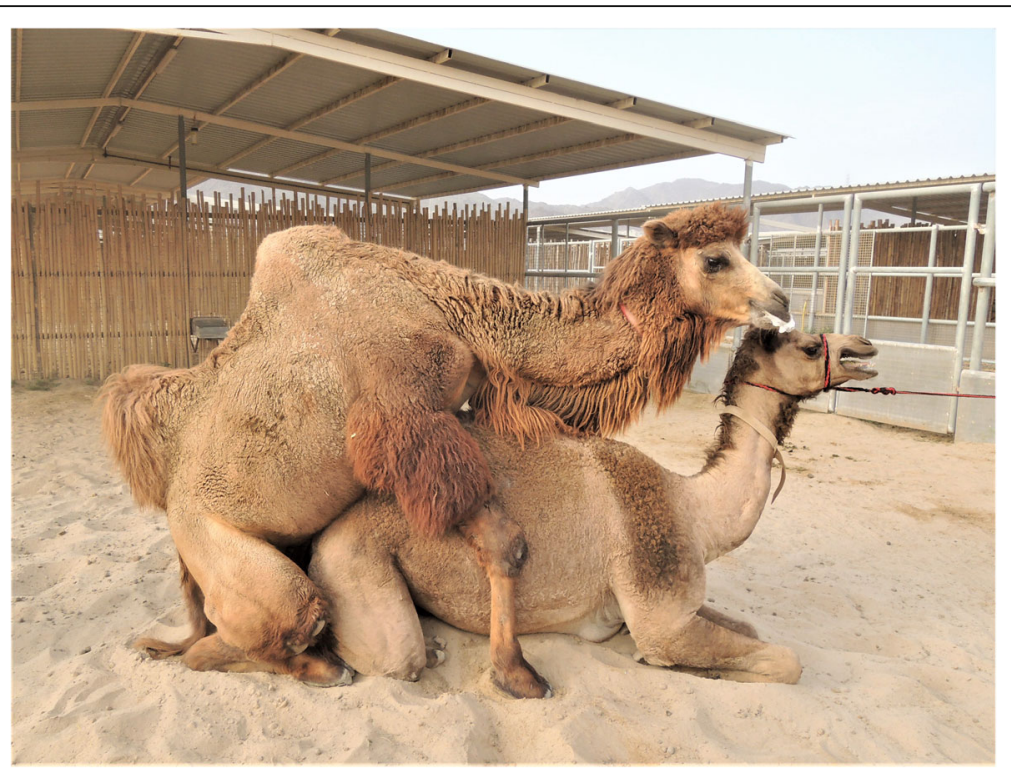

Fig. 7 A Bactrian camel male mating with a female dromedary. Note the position of the male front legs comfortably straddling the female and so conferring stability to the male position

shoulder and extends well over the lumbar vertebrae. The peculiar shape is named "almond hump" or badem horguc in Turkish (Fig. 8). In addition to being unusually elongate, the hump of an F1 hybrid in the anterior area has a small indentation or notch a few centimetres deep. This is clearly visible in wellnourished hybrid camels with short hair or detectable by manual palpation in the case of hybrid camels with a long coat. F1 hybrids possess also abundant hair all along the front side of the neck, the top and back of the head, and the forearms. Further F2 crosses between F1 are not done since the resulting progeny, named kukirdi, have substandard body development (Dzhumagulov 1980) and reputedly poor behavioural qualities to such an extent that these has been described as "a menace to the mother and the herd" (Çakırlar and Berthon 2014). However, further hybridization is occasionally done using the "backcross" method in which the males and females of the first cross-breeding are mated to dromedary or Bactrian camels obtaining second-generation hybrids (F2). They are named tavsi, when the female F1

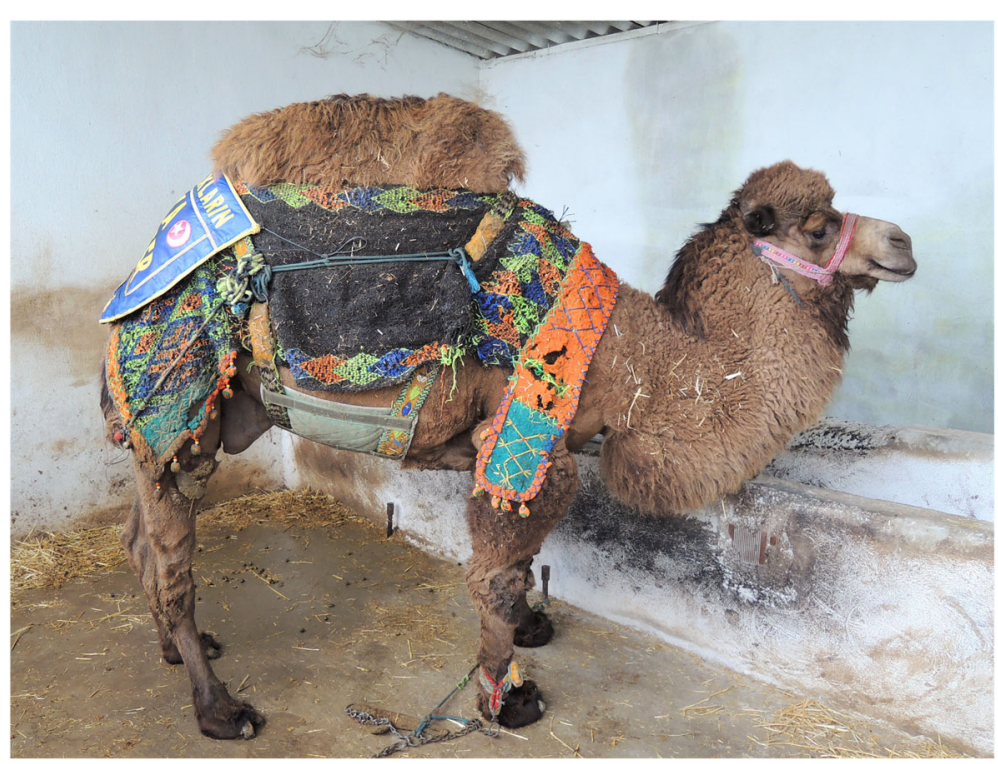

Fig. 8 A Turkish F1 hybrid tülü showing the typically elongated hump named "almond hump" in Turkish 
maya is bred with a male Bactrian camel, and teke, when a male F1 tülü is bred with a female dromedary. They are not used in wrestling, but as working animals, tavsi for colder areas and teke for the hotter areas of southern Turkey. F1 maya may also be bred to a male dromedary producing an F2 hybrid camel named yegen; however, this is only done occasionally since his performance qualities are not appreciated (Yilmaz et al. 2015a, b). Further cross-breeding is done to produce F3 animals by back-crossing a female teke with a Bactrian camel; such hybrids are called kertelez and because of the higher Bactrian genetic influence, they are adapted to colder and hilly areas of Turkey such the Taurus mountains.

\section{Hybrid production methods from Kazakhstan}

Kazakhstan, being the largest country in former Soviet Central Asia with a population of both dromedaries and Bactrian camels, has the most complex camel hybridization practices with well-established cross-breeding strategies developed by Russian and Kazakh scientists (Dzhumagulov 1980; Baimukanov 2002; Ruchkina and Vakhitova 2008). There are many regional linguistic differences and dialects; therefore, the terminology identifying

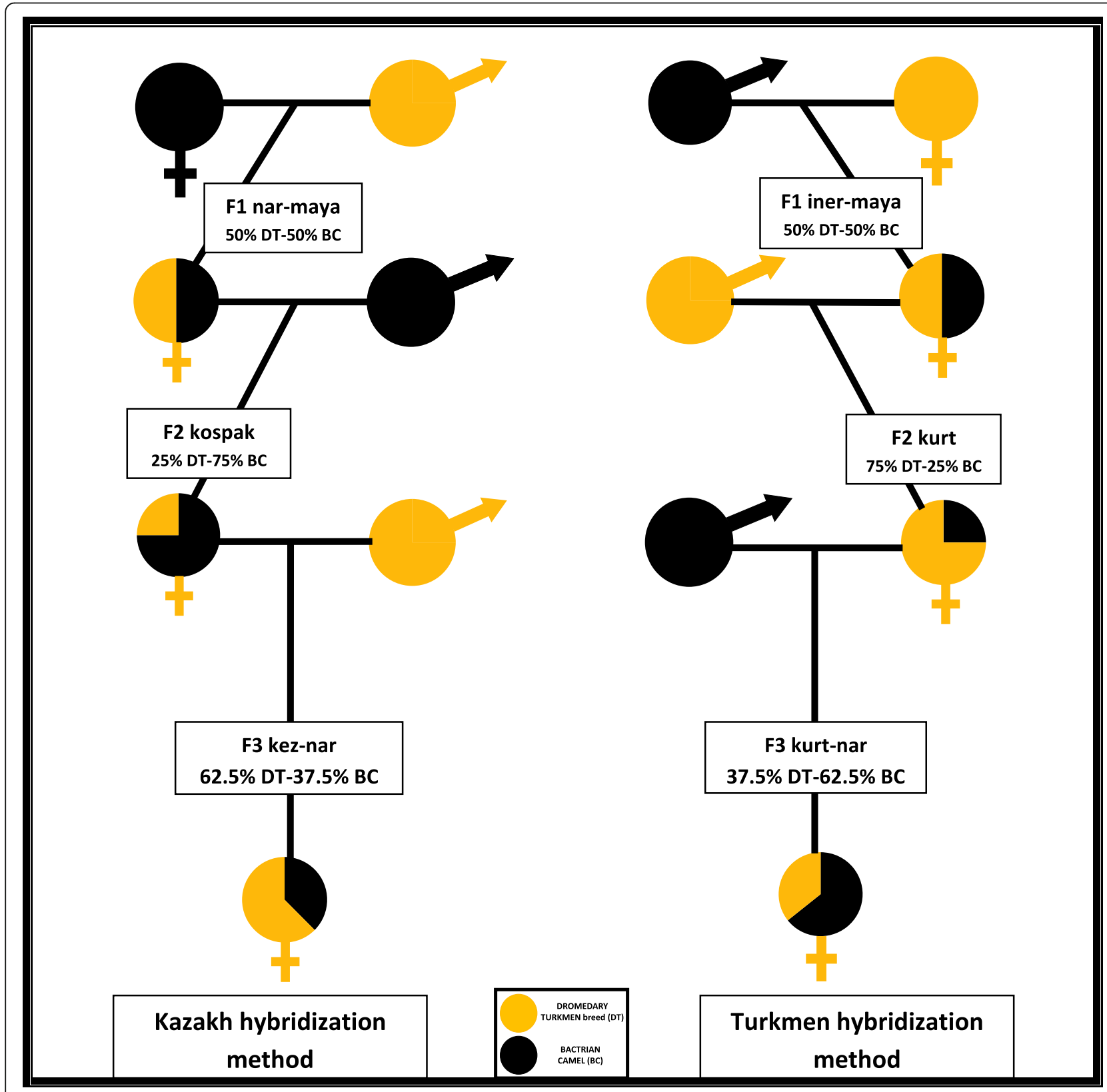

Fig. 9 Basic cross-breeding methods adopted in Russia, Kazakhstan, and neighbouring countries 
hybrids is complex (Bulliet 1975; Sala and Kartaeva 2017; Tapper 1985) and prone to confusion and inconsistencies on the correct terms for specific hybrids (Imamura et al. 2016). This article follows the latest hybrid etymology adopted by Baimukanov et al. (2019). Two main cross-breeding methods are adopted, both initially based on a two-breed cross followed by various stages of back-crossing and are illustrated in Fig. 9. The so-called "Turkmen Hybridization Method" in which the first generation (F1) of camel hybrids is produced crossing a male Bactrian camel with female dromedary results in a hybrid camel named iner-maya for female and iner for male. The "Kazakh Hybridization Method" in which a male dromedary is crossed with a female Bactrian camel results in a F1 hybrid female camel named nar-maya and a male named nar (Baimukanov et al. 2018, 2019) (Fig. 10). This method is possible because both the Kazakh breed of dromedary and the Turkmen dromedary or arvana (Fig. 11), has a large and longbodied conformation that allows the male to overcome the obstacle of the female Bactrian camel rear hump when mating. Both dromedary and Bactrian camel mate in a crouched position; however, when a female Bactrian camel is mated with a male dromedary, her rear hump forces a short-bodied mating male dromedary to assume a very erect position which is unstable. In such circumstances, the male often slides down sideways away from the female and is unable to complete the mating. F1 hybrids, iner-maya and narmaya, or bir-tygan in Kyzylorda region of Kazakhstan, do not differ much from each other. Both have a single very large hump extending from the shoulder to the lumbar area with a distinct notch, a few centimetres deep, on the front of the hump. These hybrids have also more hair than the pure-bred dromedary and in the same body areas of Bactrian camels: neck, head, hump, and forearms. As in the case of horse cross-breeds, the phenotype of the mother is slightly more obvious (Lin et al. 2016) and so iner-maya hybrids tend to look more like a dromedary while nar-maya inherit more Bactrian camel characteristics, particularly neck and forearm hair (Ruchkina and Vakhitova 2008).

Male and female F1 hybrids are not bred among themselves since with such breeding the advantages of heterosis, hybrid vigour, disappear. Furthermore, their progeny, jarbal or jarbay or dzharbai, have poor body development with deformed chest and joints and an unsound temperament (Baimukanov 2002; Dzhumagulov 1980; Ruchkina and Vakhitova 2008). All further crossings of F1 hybrids are therefore based on a back-crossing system: female F1 are mated with one of their original species, while male F1 are usually castrated (Ruchkina and Vakhitova 2008). The back-crossing of nar-maya (F1) females with male Bactrian camels produces a group of F2 hybrids named kospak, whose females will subsequently be mated with Turkmen male dromedaries to produce a group of F3 hybrid camels named kez-nar. Iner-maya (F1) females back-crossing with male Turkmen dromedaries produce a group of F2 hybrids named kurt whose females will later on be mated with male Kazakh Bactrian camels to produce a group of F3 camel hybrids named kurt-nar (Figs. 12 and 13).

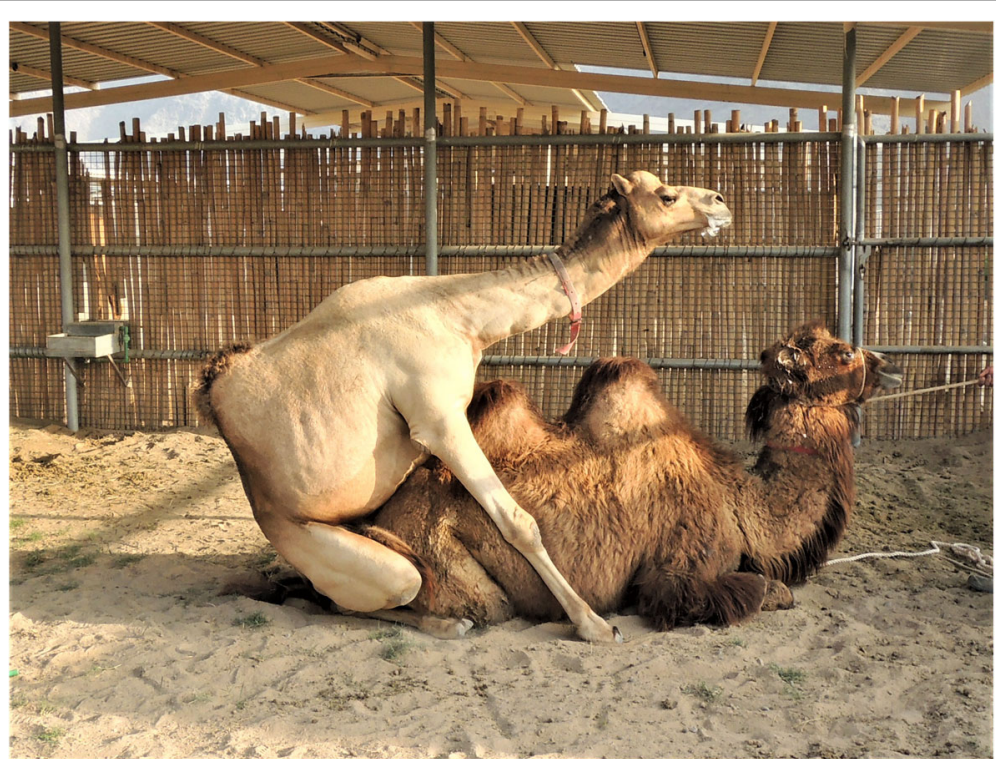

Fig. 10 A dromedary male mating with a Bactrian camel female. The rear hump of the female and the short-bodied conformation of the male is forcing the male to assume a very erect mating position. In such conditions, the mating dromedary front legs are unable to reach the ground and the male loses balance and slide down on the female side and is unable to complete the mating 


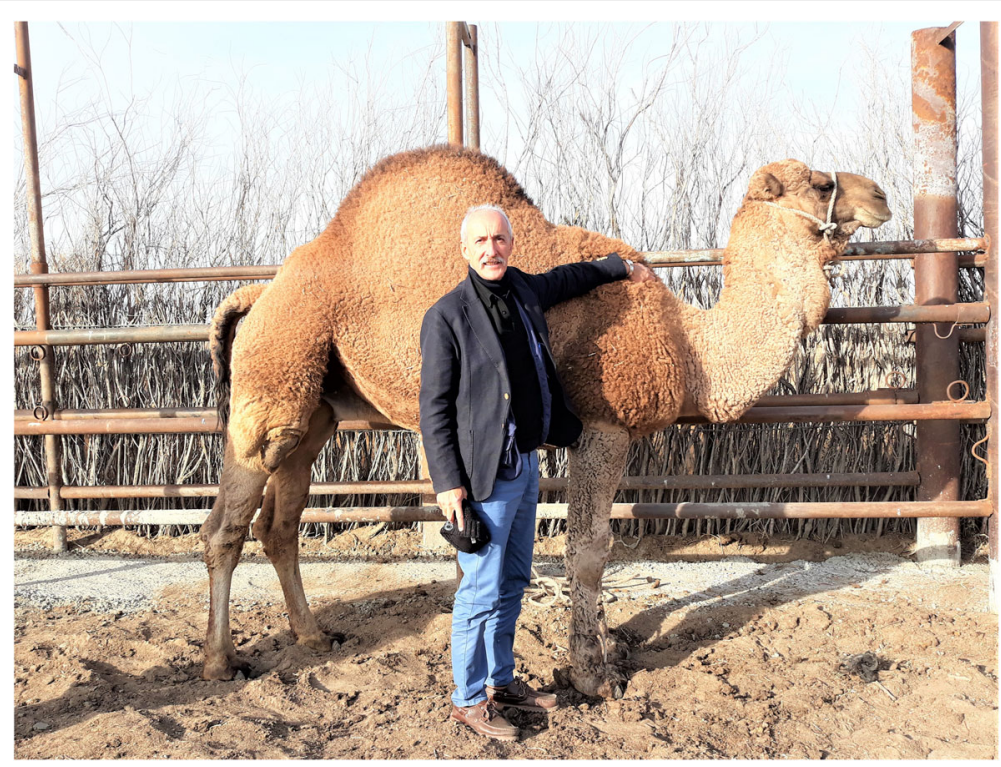

Fig. 11 An adult dromedary male stud of the Arvana breed. This dromedary breed is long-bodied and large with a big elongated hump and dense brown coat. The breed is tolerant to cold wet conditions and has good milk production of 10-15 I daily. Man height, $1.85 \mathrm{~m}$

The "Turkmen Hybridization Method" and the "Kazakh Hybridization Method" have been known at least for several decades (Dzhumagulov 1980); however, renewed interest in Kazakhstan toward achieving a more profitable utilization of the dromedaries and Bactrian camels resulted in the development of more complex hybridization schemes.

\section{Modern variations of the Turkmen Hybridization Method}

Figure 14 summarizes the various modifications done by Kazakh scientists to the Turkmen Hybridization Method. As in the original hybridization scheme, the iner-maya, obtained by crossing a female dromedary with a male Bactrian camel, is back-crossed with a male

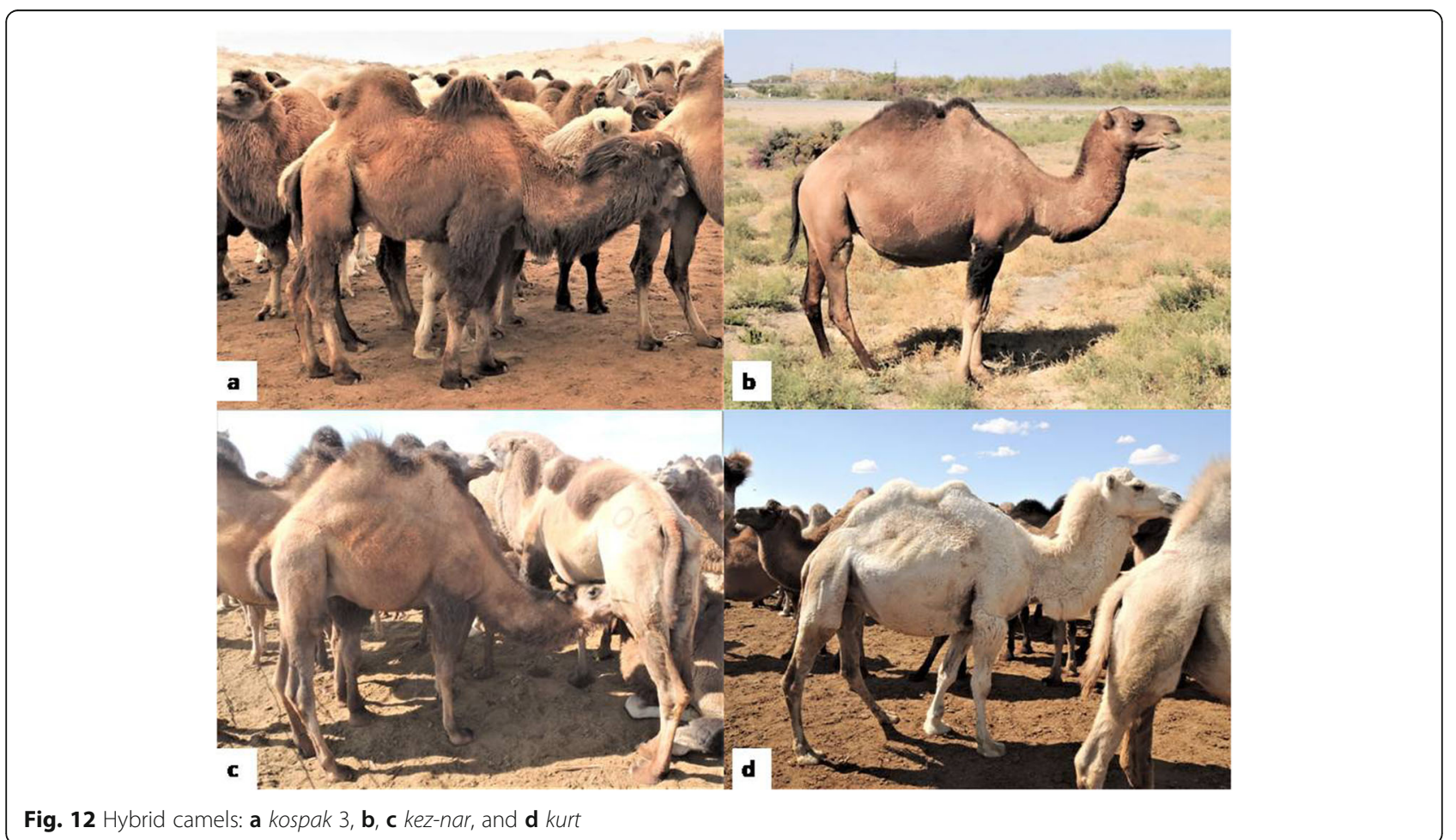




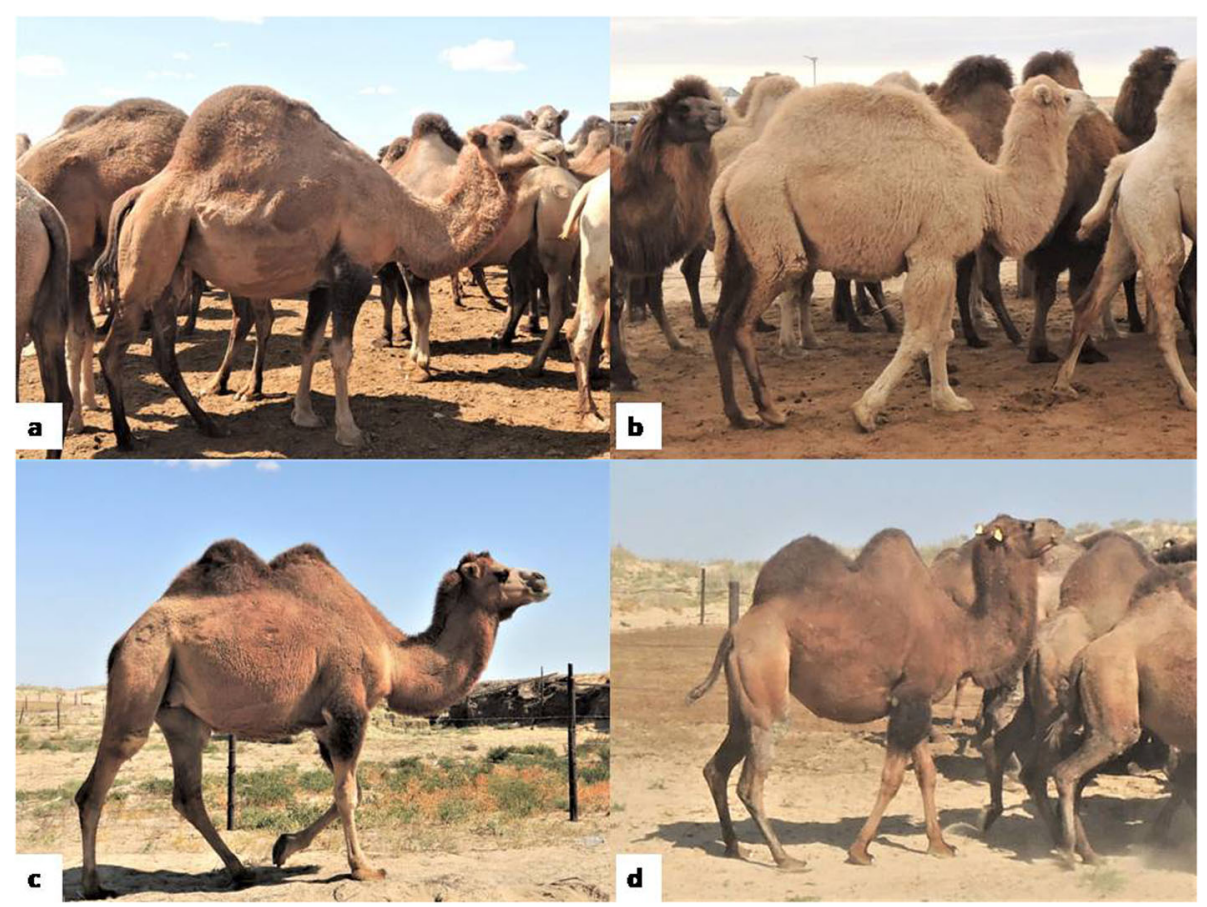

Fig. 13 Hybrid camels: a iner-maya, b nar-maya, c kospak 1, and d kospak 2

dromedary of Turkmen breed to give birth to an F2 hybrid named kurt. After this, different cross-breeding strategies are implemented. The first F2, kurt or kurt 1, is again back-crossed with a Turkmen dromedary to produce an F3 hybrid named kurt 2, or sapaldryks, and this then back-crossed again with a Turkmen dromedary to produce an F4 hybrid (fourth filial generation) named kurt 3. This hybrid finally is back-crossed yet again to produce an F5 hybrid (fifth filial generation) named kurt 4. This last hybrid, with $96.8 \%$ Turkmen dromedary genes and only $3.12 \%$ Bactrian camel genes, is then developed further by breeding among itself and creating a new breed, the so-called Kazakh dromedary (Baimukanov 2019; Kazakhstan Patent Database 2003). Phenotypically, this new breed is indistinguishable from a dromedary since the three successive back-crossings with the Turkmen dromedary have stabilized the shape of their single hump and removed the presence of the typical Bactrian body hair on the neck, forearms, and head (Fig. 15). However, the milk of Kazakh dromedary has a higher fat content percentage than the milk of the Turkmen dromedary with an average fat content of $4.5 \%$ (Baimukanov et al. 2019) compared to the dromedary mean fat content \% of $3.52 \pm 0.74 \%$ (Zhao et al. 2015). F3 kurt 2 can also be bred among themselves producing an F4 commercial hybrid simply known as "hybrid". However, female kurt hybrids are often back-crossed with pure Bactrian camels. In such cases, F2 kurt 1 give birth to an F3 hybrid named kurt-nar 1 while F3 kurt
2 produce an F4 hybrid named kurt-nar 2 (Kazakhstan Patent Database 2009a).

A three-breed cross can be carried out crossing an F4 kurt-nar 2 hybrid with a Kazakh dromedary producing a new type of F5 hybrid called baytur (Kazakhstan Patent Database 2010c). A three-breed cross is also done crossing a female F2 kurt 1 with the Kazakh dromedary male to obtain a new type of F3 hybrid named bai-nar (Kazakhstan Patent Database 2005). Bai-nar may occasionally be crossed with the new Kazakh dromedary or a pure-bred Bactrian camel, generating hybrids that are reported to reach maturity at an earlier age. One can also cross an F3 kurt 2 again with a Kazakh dromedary male to obtain a new type of F4 hybrid named bekdas. Finally, bekdas can be back-crossed with a Kazakh dromedary producing a new type of F5 hybrid named bekdas-nar (Kazakhstan Patent Database 2010d).

Within the Turkmen Hybridization Method, further utilization of a "three-breed cross-breeding" using the new breed of Kazakh dromedary has led to the creation of new hybrids. Figure 16 illustrates the various steps. It begins by crossing a male of the new Kazakh dromedary with a female F1 iner-maya to produce a new F2 hybrid named bayshin. This will then be back-crossed with a pure male Bactrian camel generating a new F3 hybrid named baykazhy-nar. Females of this new hybrid will be further backcrossed with a male Turkmen dromedary producing a new F4 hybrid named ardas which will be back-crossed again 


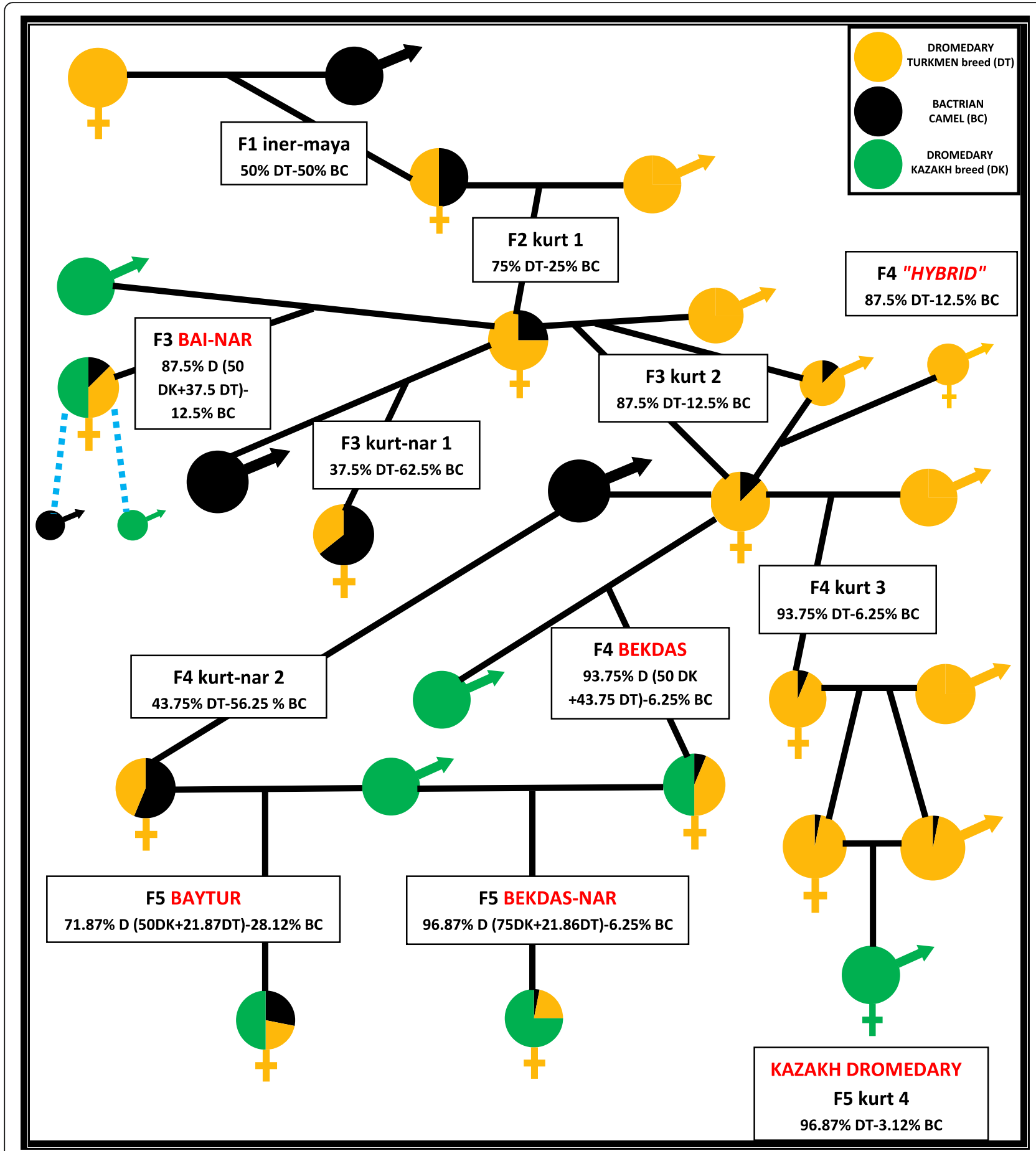

Fig. 14 Modern variations of the Turkmen Hybridization Method leading to the production of new hybrids: bai-nar; bekdas and bekdas-nar; baytur; kurt-nar, kurt 1, 2, and 3; and "Kazakh dromedary" 


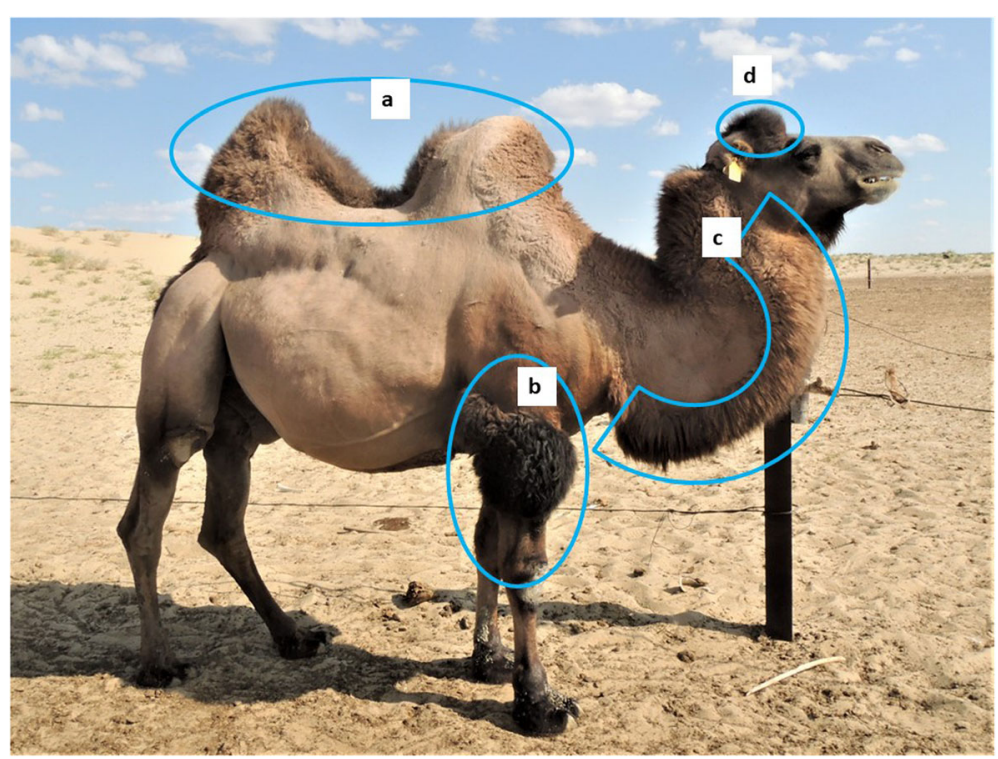

Fig. 15 Typical phenotypic characters of Bactrian camel: (a) two humps with their bases separated by $30-40 \mathrm{~cm}$ or more of flat area; (b) abundant forearms hair; (c) abundant hair localized on the front margins of the neck, from the throat area to the neck base; and (d) abundant hair on the top of the head between the ears. These areas of hair growth are absent in pure dromedaries while these are always present in varying degree in hybrids

with a Kazakh dromedary to produce a new F5 hybrid named sannak (Baimukanov et al. 2016, 2017b, 2019).

\section{Modern variations of the Kazakh Hybridization Method}

The Kazakh Hybridization Method has been further modified by Kazakh scientists. Two main breeding plans have been developed, one involving crossing the narmaya with the newly developed breed of Kazakh dromedary and another one using the Turkmen breed of dromedary. Figure 17 schematically shows the first approach. It is a three-way cross using the newly developed breed Kazakh dromedary. The F1 nar-maya is backcrossed with a male of Kazakh dromedary to produce a new F2 hybrid named aydaramir-arada. This hybrid will be then back-crossed to a Bactrian camel to produce a new F3 hybrid named aydaramir-nar that will be again back-crossed to a dromedary of the Turkmen breed to produce a new F4 hybrid named aydaramir-kurt. This latest hybrid will finally be back-crossed to the new breed of Kazakh dromedary obtaining a new F5 hybrid named aydaramir (Baimukanov et al. 2019). The second hybridization strategy consists of crossing the F1 narmaya with a male dromedary of the Turkmen breed to obtain an F2 hybrid arada-kurt (also named Dostik 1). This hybrid will be crossed with the new breed of Kazakh dromedary obtaining a new F3 hybrid named arada-nar. Such hybrids are further developed and allowed to breed "in itself" ultimately producing an F4 hybrid that is considered a completely new camel breed named arada. The new breed has a Bactrian camel genetic make-up of $12.5 \%$ and a dromedary heritage of $87.5 \%$ made up by the Turkmen dromedary breed (37.5\%) and the new Kazakh dromedary breed (50\%) (Kazakhstan Patent Database 2009b). F2 arada-kurt may also be used to develop a line of hybrids named Dostik by back-crossing repeatedly with dromedaries of the Turkmen breed. The mating generates an F3 hybrid named Dostik 2 and subsequently an F4 hybrid Dostik 3. These latest hybrids are bred among each other and generate an F5 hybrid simply named type Dostik 3 (Baimukanov et al. 2013; Kazakhstan Patent Database 2014).

The second variation of the Kazakh Hybridization Method is shown in Fig. 18 (Baimanukov 2019, Kazakh Patent Database 2008a, 2009c, 2010a, b). With this breeding method, the F1 nar-maya is back-crossed to a male Bactrian camel to produce an F2 hybrid named kospak 1 or bal-kospak. This hybrid is then further backcrossed with a Bactrian male to obtain a new F3 hybrid named kopsak 2 or myrza kospak, and again to obtain a new F4 hybrid named kospak 3 or nar-kospak (Kazakhstan Patent Database 2008b). All the hybrid kospaks can be back-crossed with Turkmen dromedaries to produce various types of hybrids named kez-nars. F2 kospak 1 produces F3 kez-nar 1, F3 kospak 2 produces an F4 kez-nar 2, and F4 kospak 3 produces an F5 keznar 3 (Kazakhstan Patent Database 2008a).

An important addition to this cross-breeding scheme consists of introducing a "three-breed cross-breeding" strategy crossing the F2 hybrid kospak with the new breed of Kazakh dromedary and by doing so generating a completely new F3 hybrid named baidara (Kazakhstan Patent 


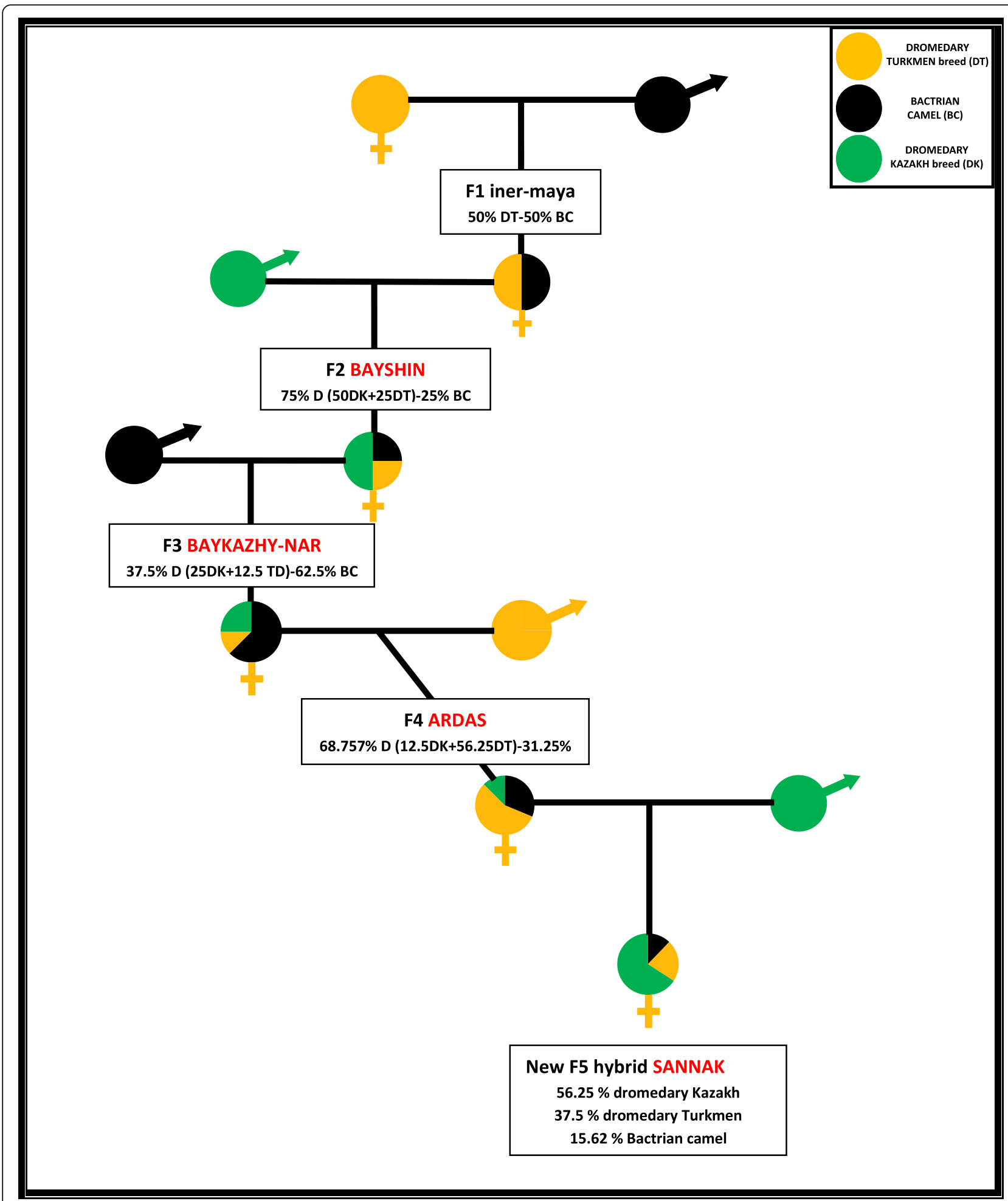

Fig. 16 Turkmen Hybridization Method utilization of a "three-breed cross-breeding" using the new breed of Kazakh dromedary to produce new hybrids: bayshin, baykazhy, ardas, and sannak 


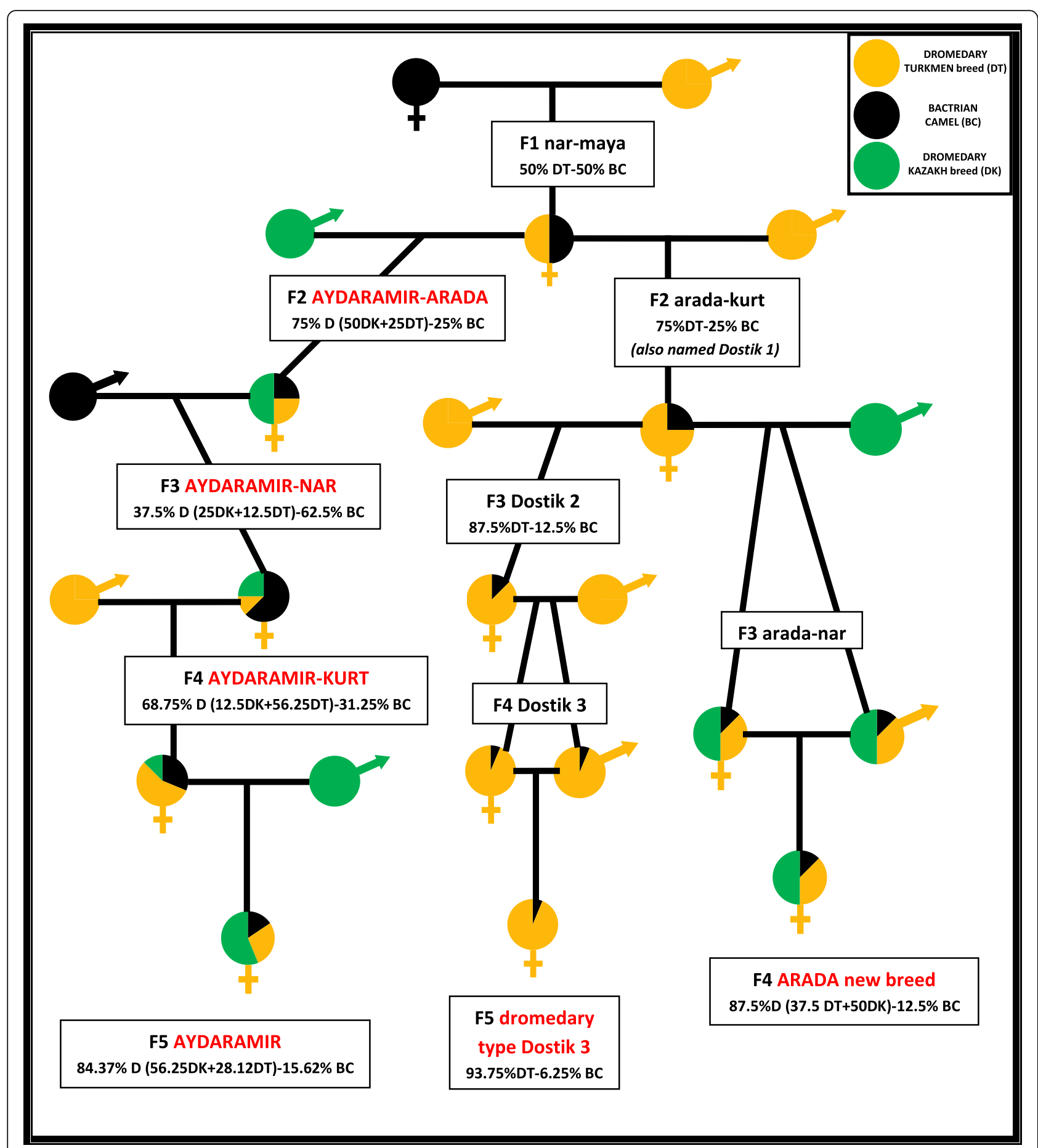

Fig. 17 Modern variations of the Kazakh Hybridization Method leading to the production of new hybrids: dromedary type Dostik 3, arada, and aydaramir 


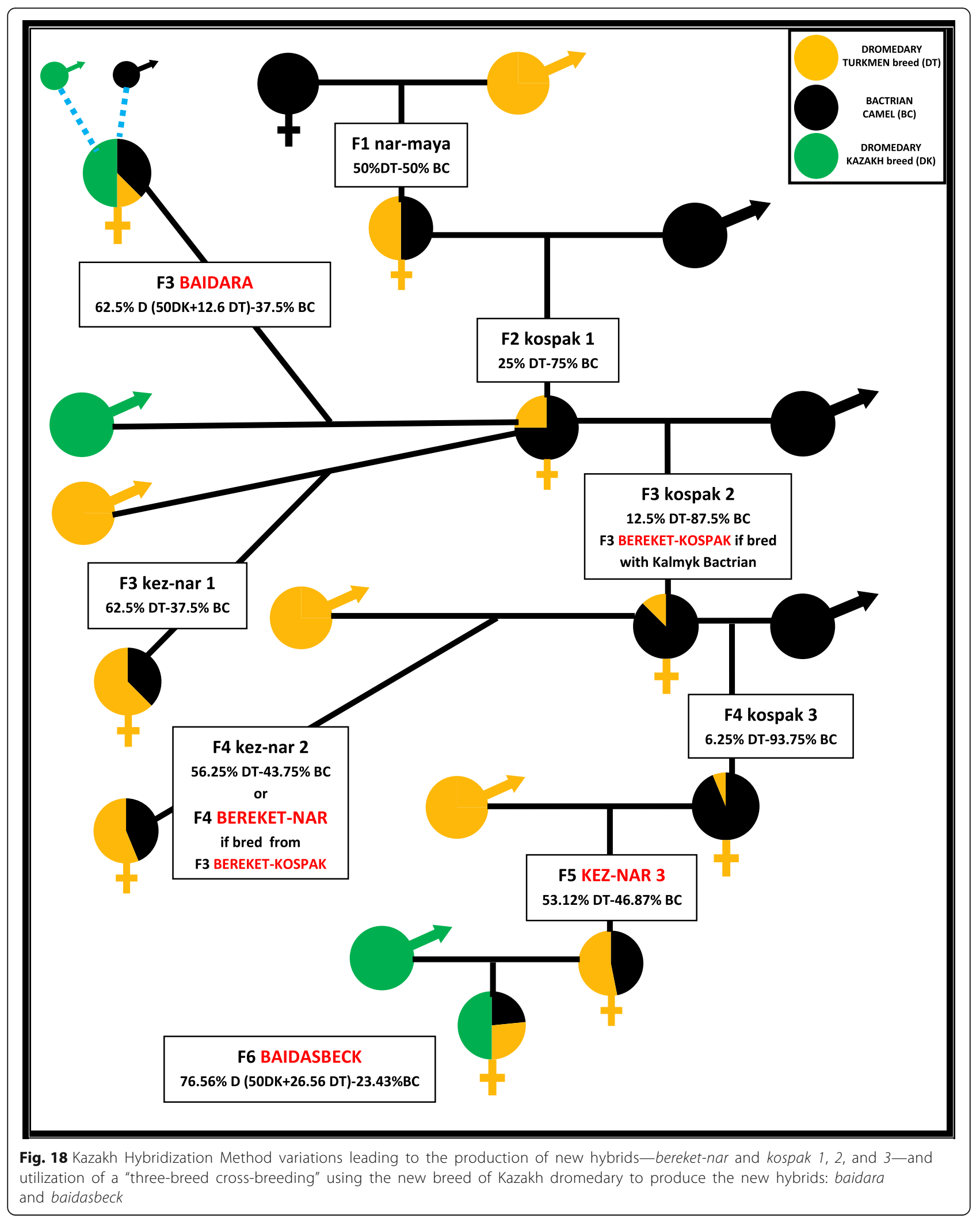


Database 2009c). Baidara may occasionally be crossed with the new Kazakh dromedary or a pure-bred Bactrian camel as this seems to increase early reproductive maturity. The Kazakh dromedary is also utilized by crossing it with a female F5 kez-nar 3 to produce a new F6 hybrid (sixth filial generation) named baidasbeck (Kazakhstan Patent Database 2010b). Recently, a variation of this scheme has been added by utilizing the larger breed of Bactrian camel: Kalmyk breed (Fig. 19). When crossing a female F3 kospak with a male Bactrian camel of Kalmyk breed, a valuable new F3 hybrid is obtained named bereket-kospak, which produces a new F4 hybrid named bereket-nar when crossed with a male Turkmen dromedary (Kazakhstan Patent Database 2010a).

\section{Overview of main established hybrid advantages}

The main objective of dromedary and Bactrian camel cross-breeding practices developed by Kazakh and Russian scientists has been to develop a camel breed with higher milk production capabilities than the Bactrian camel as well as the ability to survive the harsh climate of Central Asia essentially in a free-range situation. The climatic conditions of such regions are characterized by hot summers and snowbound winters with severe subzero temperatures. Numerous hybrids with such qualities have been developed. Of particular interest are bainar, baykazhy, aydaramir-arada, aydaramir-nar, baidasbeck, and baidar hybrids which have a higher milk production than the Turkmen dromedary. Meanwhile the F2 hybrids: bayshin, and aidaramyr-nar, all F4 hybrids (excluding kurt 3) and F5 hybrids sannak, and aidaramyr have a higher live weight than the dromedary and the Bactrian camel. The work of Russian and Kazakh researchers (Baimukanov et al. 2016, 2017a, b, c, 2018, 2019; Dzhumagulov 1980) has established the following general rules concerning camel hybridization practices:

- Breeding hybrid males is not recommended (except F5 kurt 4, F4 Dostik 3, F3 arada-nar).

- F1 hybrids are 5-12\% larger in body size than each of their own pure-bred parents, the dromedary and Bactrian camel, and with better working ability and higher endurance. F1 hybrids obtained with the Kazakh Hybridization Methods are larger than F1 obtained with the Turkmen Hybridization Method. The positive effects of heterosis are greater from the age of 1 year onward.

- All hybrids have greater productive longevity than dromedary and Bactrian camels with F1 nar-maya and F3 kez-nar capable of 7.3 and 6.8 lactations in their lifetime respectively.

- When F1 hybrids breed among themselves, the positive effects of heterosis are completely absent and the resulting F2 hybrid, named jarbay, is an unfit animal.

- Hybrid calves have a higher birth weight (F1 mean birth weight, $45.4 \pm 0.842 .1 \mathrm{~kg}$ ) than the calves of dromedaries (mean birth weight, $34.5 \pm 0.09 \mathrm{~kg}$; Nagy and Juhász 2019) and of Bactrian camels (mean birth weight, $34.55 \pm 7.17 \mathrm{~kg}$; Zhao et al. 2000). Their growth rate is also higher.

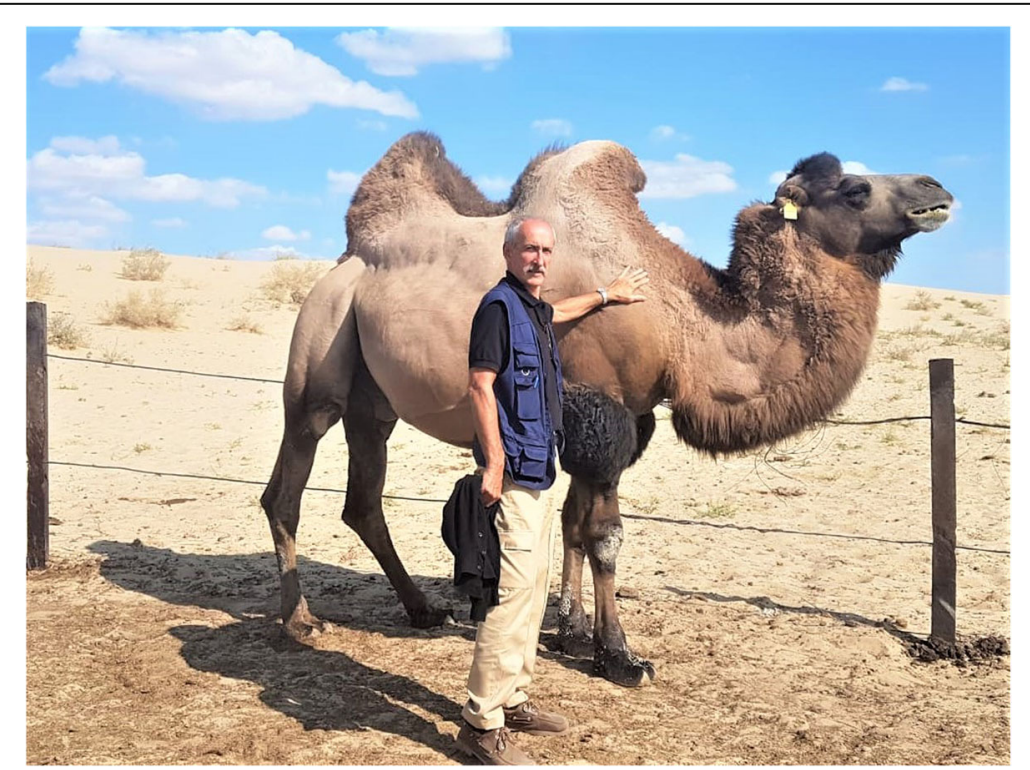

Fig. 19 Bactrian camel stud of the Kalmyk breed. This Bactrian camel breed is massive, capable to reach a live body weight of more than 1200 $\mathrm{kg}$. The breed can produce 6-9 kg of fine wool and has a daily milk production of 2.5-3.5 I. Man height, $1.85 \mathrm{~m}$ 
- Higher percentages of dromedary genes in a hybrid increases overall milk production due to: longer and more abundant lactation; improves udder size and conformation including better quarters symmetry and development; increased teats spacing, size, and downward direction. However, this also reduces fat percentage in milk, reduces wool production and early maturity as well as adaptability to colder climates.

- Higher percentage of Bactrian camel genes in a hybrid increases wool production, live weight, and fat percentage in milk but decreases lactation length and absolute milk yield. The length of pregnancy also increases.

- All hybrids have a gestation length shorter than the one of the Bactrian camel (mean $442.5 \pm 5.1$ days) but longer than that of the Turkmen dromedary (mean $425 \pm 3.9$ ) and Kazakh dromedary (mean 417.2 \pm 3.1 days). Dromedary genes shorten the duration of pregnancy. F4 hybrids have a gestation length closest to the Turkmen and Kazakh dromedary.

- All hybrids have a lower wool production than that of Bactrian camels

- All hybrids have a lower fat percentage in milk than that of Bactrian camels (mean $5.34 \pm 0.60$ ) but higher than that of pure-bred dromedaries (mean $3.52 \pm 0.74$ ) (Zhao et al. 2015)

\section{Conclusions and recommendations}

Camel hybridization may play an important role in enhancing camel productivity in all areas of Central Asia that presently keep only Bactrian camels because of the inability of dromedaries to survive in the Central Asian climate. Indeed, trends toward increasing camel milk production utilizing hybrids are already detectable in areas of Kazakhstan (Imamura et al. 2017). In many areas of Kazakhstan, dromedaries, Bactrian camels, and their hybrids are free-ranging and naturally intermingling (Fig. 20). In such conditions, unsupervised mating may occur and go unrecorded. producing animals with an unknown dromedary/Bactrian camel genetic make-up. All such hybrids, while morphologically identical to pure-bred dromedaries, still retain Bactrian camel genes that may influence a hybrid's productivity. The identification of hybrid camels based on phenotypic characters is unreliable, particularly for later stage hybrids such as F4-F6 (Table 1 and Fig. 15). Rigorous pedigree recording, combined with permanent camel identification, are therefore better tools to clearly identify individual hybrids and the exact genetic contributions of dromedary and Bactrian camel to their genetic make-up. The increasing availability of advanced techniques for genetic and parentage testing will allow a better understanding of the genetics of dromedary, Bactrian camel, and their hybrids, possibly permitting the detection of valuable genetic traits related to increased productivity or adaptability (Burger et al. 2019).

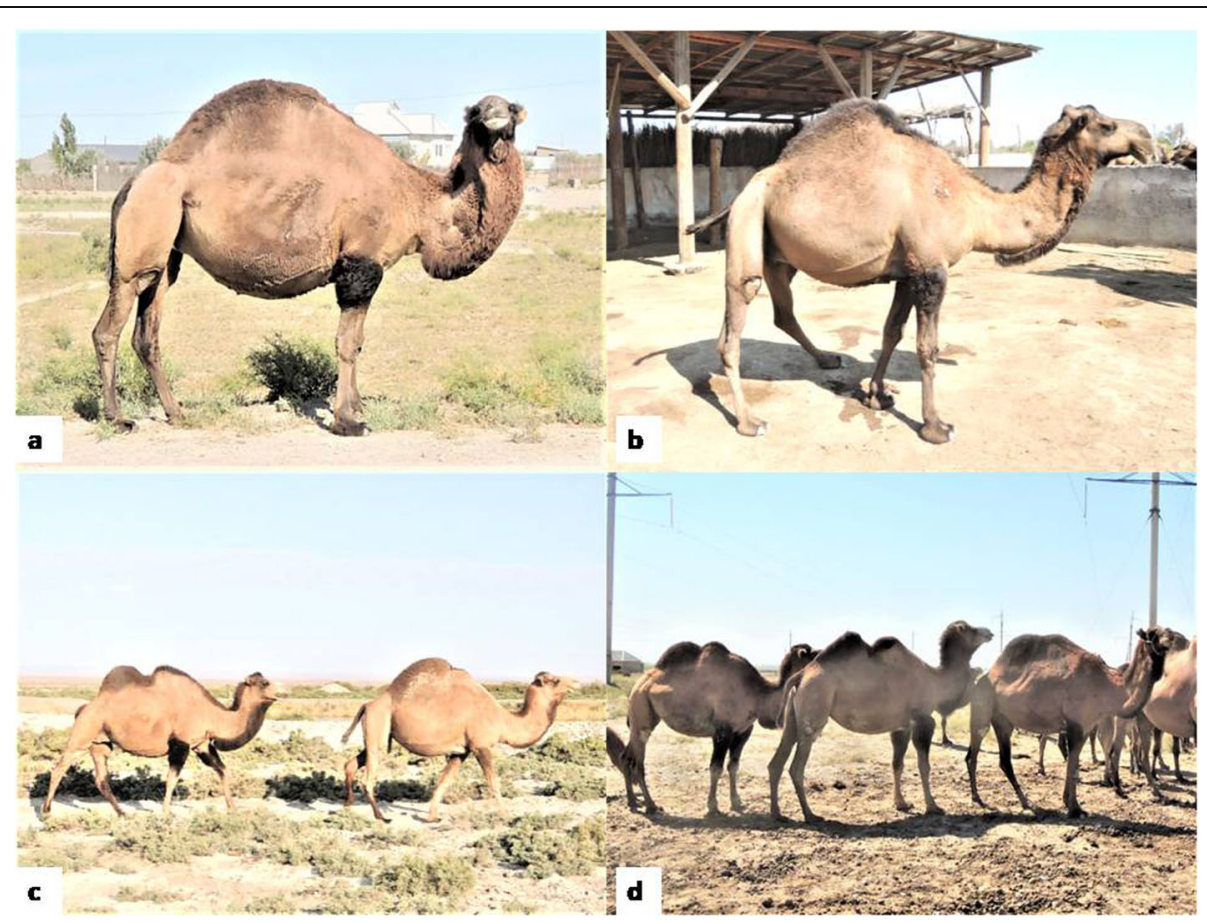

Fig. 20 a, b Hybrid camels of unknown generation possibly F4-F5. c Hybrid camels: left to right, bereket-kospak and iner-may. $\mathbf{d}$ Hybrid camels: left to right, kez-nar, kospak, and kez-nar 3 
Table 1 List of dromedary-Bactrian camel hybrids mentioning their phenotypic Bactrian characters

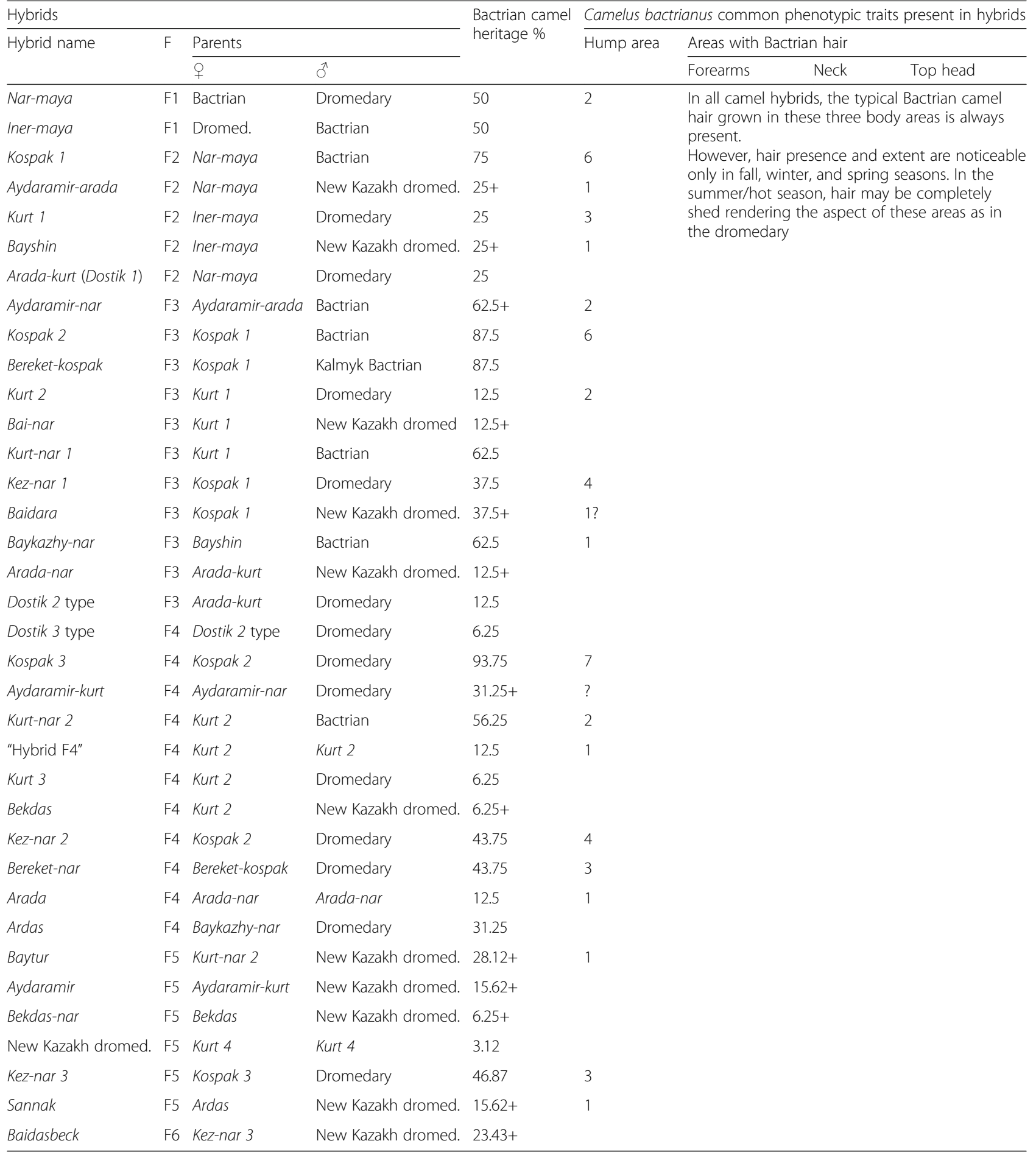

Explanatory notes: Hump area-8, Bactrian humps; 7, two well-developed humps closer than in the Bactrian but separate at their base; 6, two well-developed humps with their bases touching each other; 5 , one large hump with two symmetric small humps at the apex; 4 , one large hump with two asymmetric small humps at the apex, the rear hump bigger than the front one; 3 , one large hump with two visible mounds at the apex; 2 , one large hump with a clear depression several centimetres deep on the front top margin; 1, dromedary hump. Bactrian heritage: + , to indicate that New Kazakh Dromedary has still 3.12\% of Bactrian camel genes 


\section{Abbreviation}

F1: First filial generation

\section{Acknowledgements}

My personal thanks to His Highness Sheikh Mohammed bin Hamad bin Mohammed Al Sharqi, the Crown Prince of Fujairah, for generously promoting and supporting this camel research. Thanks to Mr. Mohamed Bin Ati, Mr. Adam, and Dr. Logman Abdalla Ahmed for their invaluable help. Sincere thanks also to Dr. Barry Greville-Eyres for editing the manuscript's English.

\section{Author's contributions}

The manuscript conceptualization, data collection, analysis, and writing were done by the author. The author read and approved the final manuscript.

\section{Funding}

Not applicable.

\section{Availability of data and materials}

All data generated or analysed during this study are included in this published article.

\section{Ethics approval and consent to participate}

Not applicable.

\section{Consent for publication}

Open access

\section{Competing interests}

The author declares that he has no competing interests.

Received: 12 November 2019 Accepted: 4 January 2020

Published online: 27 March 2020

\section{References}

Adamova, A.T., and J.M. Rogers. 2004. The iconography of a camel fight. Mugarnas Online 21 (1): 1-14. https://doi.org/10.1163/22118993 02101002.

Baimukanov, A., A.D. Baimukanov, D.A. Doshanov, O. Alikhanov, and S.E. Tulemetova. 2017b. The productivity of camels F2 in Kazakhstan Продуктивность верблюдов F2. [ в условиях Казахстана]. In Actual problems of agriculture in the mountainous territories: Materials of the International Scientific and Practical Conference, 120-123. Gorno-Altaysk: RIO GAGU, $\mathrm{S}$ [in Russian].

Baimukanov, A., D.A. Baimukanov, and V.G. Semenov. 2019. Interspecific hybridization of camels. Monograph. [Межвидовая гибридизачия верблюдов. Монография], 195. Cheboksary: [in Russian].

Baimukanov, D., A. Akimbekov, M. Omarov, K. Ishan, K. Aubakirov, and A. Tlepov. 2017a. Productive and biological features of Camelus Bactrianus - Camelus Dromedarius in conditions of Kazakhstan. Anais da Academia Brasileira de Ciencias 89 (3): 2058-2073.

Baimukanov, D.A. 2002. Cytogenetics and selection of two-humped, one-humped camels and their hybrids [Цитогенетика и селекция двугорбых, одногорбых верблюдов и их гибридов], 160. Almaty: Bastau [in Russian].

Baimukanov, D.A., O. Alikhanov, D.A. Baimukanov, and Y.A. Yuldashbaev. 2013. Intra-breed type "Dostik" one-humped population of camels Kazakh people [Внутрипородный тип "Достик" одногорбой популяции верблюдов казахский нар]. Аграрная Россия 9: 4-5 [in Russian]. https://doi.org/10. 30906/1999-5636-2013-9-4-5.

Baimukanov, D.A. A. Baimukanov, O. Alikhanov, D.A. Doshanov, K.Z. Iskhan, and D.S. Sarsenbai. 2018. Genetics of the productive profile of camels of different genotypes of the Kazakhstan population. Bulletin of National Academy of Sciences of the Republic of Kazakhstan 1 (371): 6-22 Almaty.

Baimukanov, D.A., A. Baimukanov, M. Tokhanov, U.A. Uldashbaev, and D. Doshanov. 2016. Breeding and genetic monitoring of dromedary group camels of south Kazakhstan population. Bulletin of National Academy of Sciences of the Republic of Kazakhstan 5 (363): 14-27 Almaty.

Baimukanov, D.A., A. Baimukanov, Y.A. Yuldashbaev, K. Ishan, D. Alikhanov, and D. Doshanov. 2017c. Productivity of the camels dromedary of the Kazakh type F4. [ПРОДУКТИВНОСТЬ ВЕРБЛЮДОВ ДРОМЕДАРОВ КАЗАХСКОГО ТИПА F4]. Reports of National Academy of Sciences of the Republic of Kazakhstan 4 (314): 74-84 Almaty. [in Kazakh].
Bartosiewicz, L. 1996. Camels in antiquity: The Hungarian connection. Antiquity 70: 447-453.

Bartosiewicz, L., and J. Dirjec. 2001. Camels in antiquity: Roman period finds from Slovenia. Antiquity 75: 279-285.

Bulliet, R.W. 1975. The camel and the wheel. Cambridge, Mass: Harvard University Press. Bulliet, R.W. 2009. Of Turks and camels. In Cotton, climate, and camels in early Islamic Iran: A moment in world history, 96-126. Columbia University Press.

Burckhardt, J.L. 1831. Notes on the Bedouins and Wahabys: Collected during his travels in the east / by late John Lewis Burckhardt. Vol. II. London: Colburn \& Bentley.

Burger, P.A., E. Ciani, and B. Faye. 2019. Old World camels in a modern world - a balancing act between conservation and genetic improvement. Animal Genetic. https://doi.org/10.1111/age.12858.

Çakırlar, C., and R. Berthon. 2014. Caravans, camel wrestling and cowrie shells: Towards a social zooarchaeology of camel hybridization in Anatolia and adjacent regions. Anthropozoologica 49 (2): 237-252.

De Grossi Mazzorin, J. 2006. Cammelli nell'antichita: le presenze in Italia. In Studi di Archeozoologia in onore di Alfredo Riedel, ed. B. Sala and U. Tecchiati, 231242. Bolzano; Provincia di Bolzano.

De Grossi Mazzorin, J. 2010. VIE DEGLI ANIMALI, VIE DEGLI UOMINI. Transumanza e altri spostamenti di animali nell'Europa tardoantica e medievale, 91-106. Italy: Edipuglia s.r.l.

Dioli, M. 2014. The missing hump: A clarification on the reported two-humped stage in the embryonic development of the dromedary (Camelus dromedarius). Journal of Camel Practice and Research 21 (2): 121-125.

Dioli, M. 2018. Camels in Europe: A brief history of camel hybrids and camel breeding in Europe over the last 1000 years. In Second Selçuk-Ephesus Symposium on culture of camel-dealing and camel wrestling, 18-20 January 2018, Selçuk, Izmir, ed. A. Koç and Ö.Ü.H. Erdogan, vol. 2, 8-11. Izmir.

Dzhumagulov, I. K. 1980. Interspecific hybridization of camels (Characterization of biological and productive qualities of camels, methods of breeding hybrids) [Межвидовая гибридизация верблюдов. (Характеристика биологических и продуктивных качеств верблюдов, методы разведения гибридов)], Unpublished PhD dissertation, K. A. Timiryazev Moscow Agricultural Academy, Moscow. [in Russian].

Faye, B., and G. Konuspayeva. 2012. The encounter between Bactrian and dromedary camels in Central Asia. In Camels in Asia and North Africa: Interdisciplinary perspectives on their past and present significance, ed. E.M. Knoll and P. Burger, 28-35. Vienne.

Fraser, J.B. 1825. Narrative of a journey into Khorasan, in the years 1821 and 1822 including some account of the countries to the north-east of Persia. London: Longman.

Galik, A., E. Mohandesan, G. Forstenpointner, U.M. Scholz, E. Ruiz, M. Krenn, and P. Burger. 2015. A sunken ship of the desert at the river Danube in Tulln, Austria. PLoS One 10 (4): e0121235. https://doi.org/10.1371/journal.pone. 0121235.

Imamura, K., A. Amanzholova, and R. Salmurzauli. 2016. Ethno-terminology of camels by Kazakh language. Journal of Nagoya Gakuin University 52 (2): 65-81.

Imamura, K., R. Salmurzauli, M.K. Iklasov, A. Baibayssov, K. Matsui, and S.T. Nurtazin 2017. The distribution of the two domestic camel species in Kazakhstan caused by the demand of industrial stockbreeding. Journal of Arid Land Studies 26 (4): 233-236.

Kazakhstan Patent Database. 2003. Patent of the Republic of Kazakhstan No. 13740. Method for selecting Kazakh dromedary camels for breeding [Спосо6 отбора верблюдов Казах-ского дромедара для селекции]. Publ. bull. 15/ 12/2003 No.12. [in Kazakh]. http://kzpatents.com/4-13740-sposob-otboraverblyudov-kazahskogo-dromedara-dlya-selekcii.html. Accessed 10 Oct 2019.

Kazakhstan Patent Database. 2005. Patent of the Republic of Kazakhstan No. 15885. The method of breeding hybrid camels "Bai-Nar" [Способ выведения гибридных верблюдов "Бай-Нар"]. Publ. bull. 15/07/2009 No.7. [in Kazakh]. http://kzpatents.com/0-pp15885-sposob-vyvedeniya-gibridnyh-verblyudovbajj-nar.html. Accessed 10 Oct 2019.

Kazakhstan Patent Database. 2008a. Patent of the Republic of Kazakhstan No. 14148. Method for the production of hybrid camels kez-nar [Спосо6 получения гибридных верблюдов кез-нар]. Publ. bull. 15/08/2008 No.8. [in Kazakh]. http://kzpatents.com/4-14148-sposob-polucheniya-gibridnyhverblyudov-kez-nar.html. Accessed 10 Oc 2019.

Kazakhstan Patent Database 2008b. Patent of the Republic of Kazakhstan No. 14890. Method for selection of Cospack hybrid camels [Способ селекции гибридных верблюдов коспак]. Publ. bull. 15/08/2008 No.8. [in Kazakh]. http://kzpatents.com/4-14890-sposob-selekcii-gibridnyh-verblyudov-kospak. html. Accessed 10 Oct 2019. 
Kazakhstan Patent Database. 2009a. Patent of the Republic of Kazakhstan No. 14147. Method for the production of hybrid camels "Kurt-nar" with increased fitness. [Способ получения гибридных верблюдов «Курт-нар» с повышенной приспособленностью]. Publ. bull., 15/07/2009 No.7. [in Kazakh] http://kzpatents.com/4-14147-sposob-polucheniya-gibridnyh-verblyudov-kurtnar-s-povyshennojj-prisposoblennostyu.html. Accessed 10 Oct 2019.

Kazakhstan Patent Database. 2009b. Patent of the Republic of Kazakhstan No. 15452. Method for producing hybrid camels "Arada" ГСпособ получения гибридных верблюдов «Арада».]. Publ. bull. 15/07/2009 No.7. [in Kazakh]. http://kzpatents.com/5-15452-sposob-polucheniya-gibridnyh-verblyudovarada.html. Accessed 10 Oct 2019.

Kazakhstan Patent Database. 2009c. Patent of the Republic of Kazakhstan No. 15884. The method of breeding hybrid camels "Baidara" meat and milk direction of productivity [Способ выведения гибридных верблюдов «Байдара» мясо-молочного направления продуктивности.]. Publ. bull. 15/ 07/2009 No.7. [in Kazakh]. http://kzpatents.com/0-15884-sposob-vyvedeniyagibridnyh-verblyudov-bajjdara-myasomolochnogo-napravleniyaproduktivnosti.html. Accessed 10 Oct 2019.

Kazakhstan Patent Database. 2010a. Patent of the Republic of Kazakhstan No. 16748. Method for the production of hybrid camels "Bereket-Nar" meat and dairy directions [Способ получения гибридных верблюдов «Берекет-нар» мясо-молочного направления]. Publ. bull. 15/01/2010 No.1. [in Kazakh]. http://kzpatents.com/5-16748-sposob-polucheniya-gibridnyh-verblyudovbereket-nar-myasomolochnogo-napravleniya.html. Accessed 10 Oct 2019.

Kazakhstan Patent Database. 2010b. Patent of the Republic of Kazakhstan No. 23600. Method for breeding hybrid camels "Baidasbek" [Способ выведения гибридных верблюдов "Байдасбек"]. Publ. bull. 15/12/2010 No.12. [in Kazakh] http://kzpatents.com/4-23600-sposob-vyvedeniya-gibridnyhverblyudov-bajjdasbek.html. Accessed 10 Oct 2019.

Kazakhstan Patent Database. 2010c. Patent of the Republic of Kazakhstan No. 23602. The method of breeding hybrid camels "Baytur" [Способ выведения гибридных верблюдов «Байтур»]. Publ. bull. 15/12/2010 No.12. (in Kazakh). http://kzpatents.com/4-23602-sposob-vyvedeniya-gibridnyh-verblyudovbajjtur.html. Accessed 10 Oct 2019

Kazakhstan Patent Database. 2010d. Patent of the Republic of Kazakhstan No. 23601. The method of breeding hybrid camels "Bekdas-nar" [Способ выведения гибридных верблюдов «Бекдас - нар»]. Publ. bull. 15/12/2010 No.12. [in Kazakh]. http://kzpatents.com/4-23601-sposob-vyvedeniyagibridnyh-verblyudov-bekdas-nar.html. Accessed 5 July 2019.

Kazakhstan Patent Database. 2014. Patent of the Republic of Kazakhstan No. 28673. Method for selecting dromedaries of the Kazakh population for breeding. [Способ отбора дромедаров казахской популяции для селекции.]. Publ. bull. 15/07/2014 No.7. [in Kazakh] http://kzpatents.com/5-ip28673-sposob-otbora-dromedarovkazahskojj-populyacii-dlya-selekcii.html. Accessed 10 Oct 2019.

Leese, A.S. 1927. A treatise on the one-humped camel in health and in disease. Stamford: Haynes \& Son.

Leonard, A.G. 1894. The camel its uses and management. London: Logman Green \& Co.

Lin, X., S. Zhou, L. Wen, A. Davie, X. Yao, W. Liu, and Y. Zhang. 2016. Potential role of maternal lineage in the thoroughbred breeding strategy. Reproduction, Fertility and Development 28: 1704-1711. https://doi.org/10.1071/RD15063.

Lombardini, L. 1879. Sui Cammelli. Ricerche. Con cenni sui nomi del Cammello del Prof. E. Teza, una carta disegnata dal Prof. G. Dalla Vedova, e sette tavole litografiche. Pisa: Tipografia Nistri.

Marsh, G.P. 1856. The camel his organization habits and uses considered with reference to his introduction into the United States. Boston: Gould and Lincoln.

Mason, I.L. 1979. Origin, evolution and distribution of domestic camels. In The Camelid: All-purpose animal. Proceedings of the Khartoum Workshop on camels, ed. R.W. Cockrill, 16-35. Uppsala.

Mukhareva, A.N. 2007. Camel scenes in the rock art of the Minusinsk Basin. Archaeology, Ethnology \& Anthropology of Eurasia 4 (32): 253-261.

Nagy, P., and J. Juhász. 2019. Pregnancy and parturition in dromedary camels I. Factors affecting gestation length, calf birth weight and timing of delivery. Theriogenology 134: 24-33. https://doi.org/10.1016/j.theriogenology.2019.05.017.

Olearius, A. 1669. The voyages and travels of the ambassadors sent by Frederick, Duke of Holstein to the great Duke of Muscovy and the King of Persia. (tr. John Davies), 2nd ed. corrected. London: Thomas Dring and John Starkey.

Peters, J., and A.V. Driesch. 1997. The two-humped camel (Camelus bactrianus): New light on its distribution, management and medical treatment in the past. Journal of Zoology 242: 651-679.

Pigière, $F$, and D. Henrotay, 2012. Camels in the northern provinces of the Roman Empire. Journal of Archaeological Science 39: 1531-1539.
Plassio, E. 1912. I/ cammello, 303. Milano: Manuali Hoepli.

Potts, D.T. 2004. Camel hybridization and the role of Camelus bactrianus in the ancient Near East. Journal of the Economic and Social History of the Orient 47 (2): 143-165.

Potts, D.T. 2005. Bactrian camels and Bactrian-dromedary hybrids. The Silk Road 3 (1): 49-58.

Ruchkina, G.A., and R.Z. Vakhitova. 2008. Camel breeding [Верблюдоводство], 142. Kostanai: Kostanaipoli Llp.D. [in Russian].

Russell, A., and P. Russell. 1794. The natural history of Aleppo: Containing a description of the city, and the principal natural productions in its neighbourhood: Together with an account of the climate, inhabitants, and diseases, particularly of the plague. London: Printed for G.G. and J. Robinson https://archive.org/details/naturalhistoryof01 russ.

Sala, R., and T. Kartaeva. 2017. Ethnic names for camel types in the Aral and Syrdarya Delta regions. Bulletin of KazNU 86 (3): 63-73 Historical Series.

Schimmer, K.A. 1847. The siege of Vienna by the Turks. London: John Murray.

Simpson, M.S. 1997. Sultan Ibrahim Mirza's Haft Awrang: A princely manuscript from sixteenth-century Iran. New Haven, CT: Yale University Press.

Steel, J.H. 1890. Manual of the diseases of the camel and of his management and uses. Madras: Lawrence Asylum Press.

Stewart, C.E. 1881. The country of the Tekke Turkomans, and the Tejend and Murghab rivers. In Proceedings of the Royal Geographical Society, 513-546.

Tapper, R. 1985. One hump or two? Hybrid camels and pastoral cultures. Production Pastorale et Société 16: 55-69.

Tapper, R. 2011. One hump or two? Hybrid camels and pastoral cultures revisited. In The Camel Conference @ SOAS 23-25 May 2011 SOAS Univ. of London. http:// www.soas.ac.uk/camelconference2011/file74604.pdf. Accessed 20 Dec 2019.

Uerpmannh, H.P. 1999. Camel and horse skeletons from protohistoric graves at Mleiha in the Emirate of Sharjah. Arabian Archaeology and Epigraphy 10 (1): 102-118.

United States Government Report. 1857. Report of The Secretary of War, communicating, in compliance with a resolution of the Senate of February 2, 1857, information respecting the purchase of camels for the purposes of military transportation. In 34th Congress, 3rd session: Senate, Ex. Doc. No. 62. 238. Washington: A. O. P Nicholson, Printer.

van Lennep, H.J. 1870. Travels in little-known parts of Asia Minor. Vol. II. London: J. Murray.

Vukovic, S., and I. Bogdanovic. 2013. A camel skeleton from the Viminacium amphitheatre. STARINAR LXIII: 251-267.

Yilmaz, O. 2017. History of camel wrestling in Turkey. International Journal of Livestock Research 7 (10): 235-239.

Yilmaz, O., F. Coskun, Y.E. Erturk, and M. Ertugrul. 2015a. Camel wrestling in Turkey. Journal of Camelid Science 8: 26-32.

Yilmaz, O., and M. Ertugrul. 2014. Camel wrestling culture in Turkey. Turkish Journal of Agricultural and Natural Sciences 2: 1998-2005.

Yilmaz, O., and M. Ertuğrul. 2015. Zootekni Bilimi Açısından Türkiye'de Deve Güreşleri. [Camel wrestling in Turkey in perspective of animal science]. Journal of Animal Production 56 (1): 70-79 [in Turkish].

Yilmaz, O., Y.E. Erturk, F. Coskun, M. Ertugrul, and T. Wilson. 2015b. Camel wrestling in Turks. Veni Vidi Vici Publishing House.

Zhao, Dian-bo, Yan-hong Bai, and Yuan-wen Niu. 2015. Composition and characteristics of Chinese Bactrian camel milk. Small Ruminant Research 127: 58-67. https://doi.org/10.1016/j.smallrumres.2015.04.008.

Zhao, X.X., H.W. Xue, Q.C. Nie, and Y.K. Zhang. 2000. Postnatal growth and development pattern of camel calves. Revue d'Élevage et de Médecine Vétérinaire des Pays Tropicaux. 53 (2): 201-208. https://doi.org/10.19182/remvt.9753.

\section{Publisher's Note}

Springer Nature remains neutral with regard to jurisdictional claims in published maps and institutional affiliations. 